\title{
Screening of Clinically Approved and Investigation Drugs as Potential Inhibitors of COVID-19 Main Protease: A Virtual Drug Repurposing Study
}

\author{
Serdar Durdagi ${ }^{1, *}$, Busecan Aksoydan ${ }^{1,2}$, Berna Dogan ${ }^{1}$, Kader Sahin $^{1}$, \\ Aida Shahraki ${ }^{1,3}$ \\ ${ }^{1}$ Computational Biology and Molecular Simulations Laboratory, Department of Biophysics, School of \\ Medicine, Bahcesehir University, Istanbul, Turkey \\ ${ }^{2}$ Neuroscience Program, Graduate School of Health Sciences, Bahçeşehir University, Istanbul, Turkey \\ ${ }^{3}$ Department of Molecular Biology and Genetics, Bogazici University, Istanbul, Turkey
}

\begin{abstract}
There is an urgent need for a new drug against COVID-19. Since designing a new drug and testing its pharmacokinetics and pharmacodynamics properties may take years, here we used a physics-driven high throughput virtual screening drug re-purposing approach to identify new compounds against COVID-19. As the molecules considered in repurposing studies passed through several stages and have well-defined profiles, they would not require prolonged preclinical studies and hence, they would be excellent candidates in the cases of disease emergencies or outbreaks. While the spike protein is the key for the virus to enter the cell though the interaction with ACE2, enzymes such as main protease are crucial for the life cycle of the virus. This protein is one of the most attractive targets for the development of new drugs against COVID-19 due to its pivotal role in the replication and transcription of the virus. We used 7922 FDA approved small molecule drugs as well as compounds in clinical investigation from NIH Chemical Genomics Center (NCGC) Pharmaceutical Collection (NPC) database in our drug repurposing study. Both apo and holo forms of target protein COVID-19 main proteases were used in virtual screening. Target proteins were retrieved from protein data bank (PDB IDs, 6M03 and 6LU7). Standard Precision (SP) protocol of Glide docking program of Maestro was used in docking. Compounds were then ranked based on their docking scores that represents binding energies. Top-30 compounds from each docking simulations were considered initially in short (10-ns) molecular dynamics (MD) simulations and their average binding energies using collected 1000 trajectories throughout the MD simulations were calculated by Molecular Mechanics Generalized Born Surface Area (MM/GBSA) method. Selected promising hit compounds based on average MM/GBSA scores were then used in long (100-ns) MD simulations. These numerical calculations showed that the following 6 compounds can be considered as COVID-19 Main Protease inhibitors: Lasinavir, Brecanavir, Telinavir, Rotigaptide, 1,3-Bis-(2-ethoxycarbonylchromon-5-yloxy)-2-(lysyloxy)propane and Pimelautide.
\end{abstract}

*E-mail: serdar.durdagi@med.bau.edu.tr (SD) 


\section{Introduction}

Coronaviruses (CoVs) are the family of viruses containing single-stranded RNA (positivesense) which is encapsulated by a membrane envelope. They are classified in the Nidovirales order, Coronaviridae family, which is comprised of two sub-families and about 40 known species. These species are divided and characterized into four gene era (alpha, beta, gamma and delta), and only the alpha and beta- strains are identified to be pathogenic to human and other mammals ${ }^{1,2}$. Before 2019, six coronaviruses were known to cause respiratory and enteric diseases in humans, especially the two of them belonging to betaviruses cause severe illness: SARS (Severe Acute Respiratory Syndrome)-CoV and MERS (Middle East Respiratory Syndrome)-CoV. A novel coronavirus is discovered in Wuhan, China in late 2019, and officially named as SARS-CoV-2 (formerly 2019-nCoV) due to its genomic similarity to SARS-CoV ${ }^{1-4}$. The disease caused by this virus is officially named as Coronavirus Disease 2019 (COVID-19) by World Health Organization (WHO). Like SARS- and MERS-CoVs, SARS-CoV-2 mostly affects the lower respiratory tract to cause pneumonia, and may also affect the gastrointestinal system, kidney, heart and central nervous system, with the common symptoms including fever, cough and diarrhea ${ }^{5}$. On $11^{\text {th }}$ of March 2020, WHO declared the COVID-19 as pandemic. The first emergence of the virus was witnessed at the penultimate days of 2019 as pneumonia concentrated in Wuhan, China. The outbreak in China was then spread very quickly to the other countries and as of $23^{\text {rd }}$ March 2020, more than 300,000 individuals have been infected by SARS-CoV2 virus and it is expected that the numbers will increase in the following months. Thus, drugs and vaccines are highly in demand to control the outbreak. The genomic sequence of SARS-CoV-2 is available (GenBank ID: MN908947.3) and the initial analyses indicate that the sequence similarity of around $80 \%$ and sequence identity of more than $90 \%$ with the different essential enzymes found in SARS-CoV. Furthermore, the catalytic sites of the four key enzymes that could be the antiviral targets are vastly conserved between two coronaviruses ${ }^{6}$. SARS-CoV-2 is also reported to have the same cell-entry receptor for infection, ACE2 (Angiotensin-Converting Enzyme 2), as SARS-CoV ${ }^{7,8}$. The genome of SARS-CoV-2 encodes for different proteins and important ones are 3-chymotrypsin-like protease (3CLpro), main protease, papain-like protease, helicase, and RNA-dependent RNA polymerase which construct the non-structural proteins and spike glycoproteins which belong to structural proteins 2,9 . While the spike protein is the key for the virus to enter the cell though the interaction with ACE2, enzymes such as main protease are crucial for the life cycle of the virus. This protein is one of the most attractive targets for the development of new drugs against SARS-CoV2 due to its pivotal role in the replication and transcription of the virus. One of the advantages of targeting this protein is that although the mutagenesis rate is high in viruses, not many happens in this protein since any mutation here can be lethal for the virus.

There are around $203 \mathrm{D}$ protein structures for SARS-CoV-2, mostly for the main protease structure in apo- and holo- states, resolved via X-ray diffraction or cryo-electron microscopy, deposited and available in Protein Data Bank (RCSB PDB). In silico studies related to main protease are increasing in terms of protein-inhibitor interactions and drug screening ${ }^{10,11}$. For a broad review of additional background, patents, developments and perspectives in COVID-19 and other diseases related to coronavirus, the reader is referred to see ${ }^{7}$.

The phenomenon known as drug repositioning or repurposing has gained attention as the development of new drug starting from the beginning becoming more costly in respect to both time and resources required. ${ }^{12-15}$ Established favorable toxicological, pharmacokinetic and pharmacodynamic properties of approved/clinical drug molecules make them suitable to be used for new indications. ${ }^{16-19}$ As the molecules considered in repurposing studies passed through several stages and have well-defined profiles, they would not require prolonged pre- 
clinical studies and hence, they would be excellent candidates in the cases of disease emergencies or outbreaks. ${ }^{20-21}$ Drug repurposing studies have already been conducted for various kind of diseases (review articles for different diseases ${ }^{16,21-24}$ ). Thanks to repositioning studies, different compounds have been found new usages than their original purposes ${ }^{21,25}$ even tough they have been failed in their original purpose and/or withdrawn from the market. ${ }^{26}$ Computational approaches such as virtual screening would decrease the times required for the identification of new targets for the existing drug molecules with the advantage of also being cost-efficient as demonstrated in review articles. ${ }^{18,25,27}$

In our group, virtual screening of different ligand databases including FDA approved drugs have been performed vastly in recent years by an in-house script and it is shown that the obtained results by this screening algorithm which is a hybrid algorithm of ligand- and targetdriven based screening techniques gave successful results. ${ }^{28-32}$ Thus, in the current study, this hybrid algorithm is applied for the identification of approved compounds against COVID-19 main protease enzyme.

\section{Results and Discussion}

Main protease has been studied by different groups to find inhibitors capable of halting this enzyme activity and consequently the reproduction of the virus. After the SARS outbreak at 2003 many researches were conducted to target the main protease of the SARS-CoV. Chen et al. utilized screening approaches using a 3D model of SARS-CoV 3CLpro to screen the MDL$\mathrm{CMC}$ database that contains 8.000 compounds $^{33}$. Cinanserin was among the high-ranked final compounds for which in vitro studies were performed. The proteolytic activity of the enzyme was shown to be inhibited by 70 to $90 \%$ at 50 to $100 \mu \mathrm{M}$ of Cinanserin ${ }^{34}$.

In a study performed by Liu et al. ${ }^{35}$ homology modeling was used to construct a model of main protease since SARS 3CLPro was not publicly available at the time of the work. Then virtual high throughput screening was performed using different chemical libraries including The National Cancer Institute Diversity Set (230.000 compounds total), ACD-3D (Available Chemical Database, Release: ACD 3D 2002.2, 280.000 compounds in total), and MDDR-3D (MDL Drug Database Report, Release: MDDR 3D 2002.2, 120.000 compounds in total). The final hits (40 compounds) were further tested in vitro to check the inhibition activity, and 3 of them were found to inhibit the protease activity up to $40 \%$. C3930 or calmidazolium which is the antagonist of calmodulin was found as the best hit with the highest inhibition activity ${ }^{35}$.

After the recent outbreak of SARS-CoV2, many research groups have started to use screening methods to search for the inhibitors of main protease. In a recent paper, Li et al. ${ }^{36}$ have screened 8.000 molecules including the approved or experimental compounds and small molecules derived from DrugBank. The protease protein with the PDB ID 5N5O was used as target. Compounds showing better affinity than $-7.7 \mathrm{kcal} / \mathrm{mol}$ were selected as hits and experimentally unapproved ones, as well as those with strong side effects were removed from the list. The list was even shortened considering the marketability of the molecules. Prulifloxacin, Bictegravir, Nelfinavir and Tegobuvi are finally selected molecules ${ }^{37}$. In a research conducted by Chen et $a l .{ }^{38}$ apo-enzyme structure of SARS-CoV (PDB ID: 2DUC) was used to build a model for the main protease of SARS-Cov2 and MTiOpenScreen web service ${ }^{9}$ was used to screen for purchasable drugs (Drugs-lib). The library has 7.173 compounds. Autodock Vina ${ }^{39}$ was used to screen the active site at chains A and B and finally 10 and 11 drugs were selected for these chains based on the energy cut-off. ${ }^{37}$ Another recent study conducted by Jin et al. ${ }^{40}$ targeted the main protease as well. This group found some promising compounds by combining structurebased drug design approaches with screening methods. In vitro cell-based assays showed the high inhibitory effect of the finally chosen compounds on the target enzyme and antiviral activities. Virtual screening studies were performed by Jin et al. ${ }^{40}$ using a model constructed 
based on the crystal structure of COVID-19 $\mathrm{M}^{\text {pro }}$ in complex with N3 inhibitor (PDB ID: 6LU7). An in-house library containing potential binding compounds was used. Cinanserin was found as the best binding affinity to the substrate-binding pocket of the enzyme, and in vitro studies showed an $\mathrm{IC}_{50}$ of $124.93 \mu \mathrm{M}{ }^{40}$. This compound that is an antagonist of serotonin was previously found to inhibit SARS-CoV ${ }^{34}$. Fluorescence Resonance Energy Transfer (FRET)based high-throughput screening resulted in the finding of some FDA-approved drugs (disulfiram and carmofur) and other compounds which are in preclinical/clinical trial (ebselen, TDZD-8, shikonin, tideglusib, and PX-12). ${ }^{40}$

In the present study, we used 7922 compounds from NIH Chemical Genomics Center (NCGC) Pharmaceutical Collection (NPC) database (https://tripod.nih.gov/npc/) and in order to eliminate the non-specific binders, some criteria including molecular weight, between 100 to $1000 \mathrm{~g} / \mathrm{mol}$; number of rotatable bonds, $<100$; number of atoms, between 10 and 100; number of aliphatic and aromatic rings, $<10$; number of hydrogen-bond acceptor and donors, $<10$ were set and as a result the total number of compounds was decreased to 6654. These 6654 compounds were then docked to the binding cavities of apo (PDB, 6M03) and holo (PDB, 6LU7) forms of COVID-19 main protease enzyme. (Figure 1) In docking, standard precision (SP) protocol of Glide docking module of Schrodinger software was used. Tables S1 and S2 show the top-100 docking scored compounds based on the docking scores at the COVID-19 in holo and apo forms, respectively. Although recent studies have suggested that docking is a successful approach for selecting hits, since in the docking flexibility of both protein residues and docked ligand are not fully considered, ordering of compounds only by their corresponding docking scores may not potentially lead to the correct ranking of compounds. Moreover, although molecular docking studies may give an initial insight into protein-ligand interactions, it is always crucial to understand the maintenance of these interactions and perform dynamical studies such as molecular dynamics (MD) simulations. Therefore, we selected top-30 compounds from each docking simulations and initially performed short (10-ns) MD simulations for these complexes (in total 600-ns MD simulations via Desmond). An in-house script was used for the preparation of simulation boxes as well as for the analysis of MD simulations. Desmond was used in MD simulations. Tables S3 and S4 represent average $\mathrm{MM} /$ GBSA scores using collected 1000 trajectory frames of selected 30 compounds from both holo- and apo- based simulations, respectively. We also performed MD simulations for the cocrystallized ligand-bound structure using the same MD protocol for screening compounds. Figure S1 shows protein-ligand interaction diagram. The figure includes a timeline representation of the interactions and contacts (H-bonds, hydrophobic, ionic, water bridges) representing which residues interact with the ligand in each trajectory frame. Interactions that occur more than $15.0 \%$ of the simulation time in the selected trajectory $(0.00$ through 100.00 ns), are shown. The stacked bar charts are also normalized over the course of the trajectory (i.e., a value of 0.5 suggests that $50 \%$ of the simulation time the specific interaction is maintained). Results showed that the following residues are crucial for ligand binding: Thr26, His41, Met49, Asn142, His164, Glu166, Gln189, Thr190 and Gln192. Several water bridges and hydrogen bonding interactions dominate the interaction constructed from Glu166. The interaction between this residue and the screened compounds was also checked. Average MM/GBSA scores of co-crystallized ligand N3 from long MD simulations was found as $-89.34 \pm 7.68$ $\mathrm{kcal} / \mathrm{mol}$. Thus, we forwarded compounds that have better average MM/GBSA scores than a cutoff value $(-70.0 \mathrm{kcal} / \mathrm{mol})$ from short MD simulations to long MD simulations. (Table 1) Interestingly, while 9 compounds identified using target retrieved from holo-state were fitting this cutoff, only 1 compound was found from database screened at apo-state. Long (100-ns) MD simulations were performed for these identified 10 hits and average MM/GBSA scores were calculated using 1000-trajectory frames throughout the simulations. Table 1 also shows 
the corresponding mechanism of actions of identified compounds. Average MM/GBSA scores show that following 6 compounds: Rotigaptide, Lasinavir, Pimelautide, 1,3-Bis-(2ethoxycarbonylchromon-5-yloxy)-2-(lysyloxy)propane, Telinavir and Brecanavir have significant MM/GBSA scores, and throughout the MD simulations the interaction between these compounds and the crucial residues of the target were maintained. (Figures S2-S11). Other selected compounds from short MD simulations such as Arzoxifene and Truxicurium could not maintain their initial crucial interactions during the simulations.

Identified compound Rotigaptide is a drug under clinical investigation for the treatment of cardiac arrhythmias - specifically atrial fibrillation. Crucial residue interactions were formed by Thr26, His41, Phe140, Leu141, Gly143, Ser144, Met165, Glu166, Gln189, Thr190 and Gln192. (Figure S5) Three of the identified inhibitors are HIV-1 protease inhibitors (Lasinavir, Telinavir and Brecanavir). While Thr26, His41, Met165 and Gln189 were crucial residues in the enzyme inhibition for Lasinavir, corresponding residues were His41, Ser46, Glu166 and Gln189 for Brecanavir (Figures S2 and S3). Telinavir mainly constructs interactions with Leu141, Asn142, Gly143, Ser144, Cys145 and Glu166. (Figure S8) Pimelautide is an immunostimulant and its built-in adjuvants are associated with an HIV-1-derived peptide. The observed crucial residues which are maintained the interactions with the ligand during the simulations were His41, Asn142, Gly143, Cys145, Glu166 and Gln189. (Figure S4) Another drug that we identified in this study was 1,3-Bis-(2-ethoxycarbonylchromon-5-yloxy)-2(lysyloxy)propane. This compound is an orally-active pro-drug of disodium cromoglycate (DSCG). DSCG is a commonly used anti-asthmatic medicine. The maintained interactions with this drug at COVID-19 Main protease were Thr26, His41, Asn119, Asn142, Glu166, Leu167, Pro168, Thr190, and Gln192 (Figure S10).

\section{Conclusions}

In this virtual drug repurposing study, we used 7922 FDA approved drugs and compounds in clinical investigation from NPC database. Both apo and holo forms of COVID-19 main proteases were used for virtual screening. Initially, docking was performed for these compounds with two different PDB structures. The compounds were then sorted according to their docking scores which represent binding energies. The first 30 compounds from each docking simulations were initially subjected to short (10 ns) MD simulations, and average binding energies were calculated using the MM / GBSA method during MD simulations. Then, the selected promising hit compounds based on average MM/GBSA scores were used in long (100 ns) MD simulations. In total around $2 \mu \mathrm{s}$ MD simulations were performed. Both docking and MD simulations binding free energy calculations showed that holo form of the target protein is more appropriate choice for virtual drug screening studies. These numerical calculations have shown that the following 6 compounds can be considered as COVID-19 main protease inhibitors: Lasinavir, Brecanavir, Telinavir, Rotigaptide, 1,3-Bis-(2-ethoxycarbonylchromone5-yloxy)-2- (lysiloxy) propane and Pimelautide. These compounds can be clinically tested and if the simulation results validated, they may be considered to use against in COVID- 19 .

\section{Methods}

7922 compounds were downloaded from NPC database and these ligands were prepared using LigPrep module of Maestro at neutral pH (LigPrep, Schrodinger v.2017). In molecular docking we used two different proteins (apo (PDB, 6M03) and holo (6LU7) forms of COVID-19 main protease). These proteins were prepared using Protein Preparation module of Maestro. PROPKA was used for protonation states of amino acid residues. Restrained minimization was performed with OPLS3 force field for the protein using $0.3 \AA$ heavy atom convergence. 
Docking was performed with Glide/SP using default settings. Protein-ligand complexes were placed in the orthorhombic boxes with explicit TIP3P water models that have $10 \AA$ thickness from edge of target proteins. All systems were neutralized by adding $0.15 \mathrm{M} \mathrm{NaCl}$ solution. The long-range electrostatic interactions were calculated by the particle mesh Ewald method. A cut-off radius of $9 \AA$ was used for both van der Waals and Coulombic interactions. Simulations were performed in body temperature $(310 \mathrm{~K})$ and 1.01325 bar. Nose-Hoover thermostat $^{41}$ and Martyna-Tobias-Klein barostat ${ }^{42}$ was used at the simulations. The time step was 2 fs. The OPLS3 force field was used in simulations. Throughout the MD simulations, 1000 trajectory frames were recorded and Molecular Mechanics Generalized Born Surface Area (MM/GBSA) binding free energies of compounds were calculated. VSGB 2.0 solvation model at Prime module of Maestro was utilized during MM/GBSA calculations.

\section{References}

1. Chen, Y.; Liu, Q.; Guo, D., Emerging coronaviruses: genome structure, replication, and pathogenesis. Journal of medical virology 2020.

2. Paules, C. I.; Marston, H. D.; Fauci, A. S., Coronavirus infections-more than just the common cold. Jama 2020, 323, 707-708.

3. Hui, D. S.; I Azhar, E.; Madani, T. A.; Ntoumi, F.; Kock, R.; Dar, O.; Ippolito, G.; Mchugh, T. D.; Memish, Z. A.; Drosten, C., The continuing 2019-nCoV epidemic threat of novel coronaviruses to global health - The latest 2019 novel coronavirus outbreak in Wuhan, China. International Journal of Infectious Diseases 2020, 91, 264-266.

4. Song, Z.; Xu, Y.; Bao, L.; Zhang, L.; Yu, P.; Qu, Y.; Zhu, H.; Zhao, W.; Han, Y.; Qin, C., From SARS to MERS, thrusting coronaviruses into the spotlight. Viruses 2019, 11, 59.

5. Liu, C.; Zhou, Q.; Li, Y.; Garner, L. V.; Watkins, S. P.; Carter, L. J.; Smoot, J.; Gregg, A. C.; Daniels, A. D.; Jervey, S., In; ACS Publications: 2020.

6. Liu, W.; Morse, J. S.; Lalonde, T.; Xu, S., Learning from the past: possible urgent prevention and treatment options for severe acute respiratory infections caused by 2019nCoV. Chembiochem 2020.

7. Cao, Y.; Li, L.; Feng, Z.; Wan, S.; Huang, P.; Sun, X.; Wen, F.; Huang, X.; Ning, G.; Wang, W., Comparative genetic analysis of the novel coronavirus (2019-nCoV/SARSCoV-2) receptor ACE2 in different populations. Cell Discovery 2020, 6, 1-4.

8. Chen, J., Pathogenicity and transmissibility of 2019-nCoV-a quick overview and comparison with other emerging viruses. Microbes and infection 2020.

9. Li, G.; De Clercq, E., In; Nature Publishing Group: 2020.

10. Khaerunnisa, S.; Kurniawan, H.; Awaluddin, R.; Suhartati, S.; Soetjipto, S., Potential Inhibitor of COVID-19 Main Protease (Mpro) From Several Medicinal Plant Compounds by Molecular Docking Study. 2020.

11. Ryo, H.; Koji, O.; Yuji, M.; Kaori, F.; Yuto, K.; Yoshio, O.; Shigenori, T., Fragment Molecular Orbital Based Interaction Analyses on COVID-19 Main Protease - Inhibitor N3 Complex (PDB ID:6LU7). 2020.

12. Adams, C. P.; Brantner, V. V., Estimating the cost of new drug development: is it really $\$ 802$ million? Health affairs 2006, 25, 420-428.

13. DiMasi, J. A.; Florez, M. I.; Stergiopoulos, S.; Peña, Y.; Smith, Z.; Wilkinson, M.; Getz, K. A., Development times and approval success rates for drugs to treat infectious diseases. Clinical Pharmacology \& Therapeutics 2020, 107, 324-332.

14. DiMasi, J. A.; Grabowski, H. G.; Hansen, R. W., Innovation in the pharmaceutical industry: new estimates of R\&D costs. Journal of health economics 2016, 47, 20-33. 
15. Scannell, J. W.; Blanckley, A.; Boldon, H.; Warrington, B., Diagnosing the decline in pharmaceutical R\&D efficiency. Nature reviews Drug discovery 2012, 11, 191.

16. Abdelaleem, M.; Ezzat, H.; Osama, M.; Megahed, A.; Alaa, W.; Gaber, A.; Shafei, A.; Refaat, A., Prospects for repurposing CNS drugs for cancer treatment. Oncology reviews 2019, 13.

17. Corsello, S. M.; Bittker, J. A.; Liu, Z.; Gould, J.; McCarren, P.; Hirschman, J. E.; Johnston, S. E.; Vrcic, A.; Wong, B.; Khan, M., The Drug Repurposing Hub: a nextgeneration drug library and information resource. Nature medicine 2017, 23, 405-408.

18. Ma, D.-L.; Chan, D. S.-H.; Leung, C.-H., Drug repositioning by structure-based virtual screening. Chemical Society Reviews 2013, 42, 2130-2141.

19. Oprea, T. I.; Bauman, J. E.; Bologa, C. G.; Buranda, T.; Chigaev, A.; Edwards, B. S.; Jarvik, J. W.; Gresham, H. D.; Haynes, M. K.; Hjelle, B., Drug repurposing from an academic perspective. Drug Discovery Today: Therapeutic Strategies 2011, 8, 61-69.

20. Chong, C. R.; Sullivan, D. J., New uses for old drugs. Nature 2007, 448, 645-646.

21. Zheng, W.; Sun, W.; Simeonov, A., Drug repurposing screens and synergistic drug-c ombinations for infectious diseases. British journal of pharmacology 2018, 175, 181191.

22. Andrews, K. T.; Fisher, G.; Skinner-Adams, T. S., Drug repurposing and human parasitic protozoan diseases. International Journal for Parasitology: Drugs and Drug Resistance 2014, 4, 95-111.

23. Pizzorno, A.; Padey, B.; Terrier, O.; Rosa-Calatrava, M., Drug repurposing approaches for the treatment of influenza viral infection: Reviving old drugs to fight against a longlived enemy. Frontiers in immunology 2019, 10, 531.

24. Yadav, V.; Talwar, P., Repositioning of fluoroquinolones from antibiotic to anti-cancer agents: An underestimated truth. Biomedicine \& Pharmacotherapy 2019, 111, 934-946.

25. Nowak-Sliwinska, P.; Scapozza, L.; i Altaba, A. R., Drug repurposing in oncology: Compounds, pathways, phenotypes and computational approaches for colorectal cancer. Biochimica et Biophysica Acta (BBA)-Reviews on Cancer 2019.

26. Ashburn, T. T.; Thor, K. B., Drug repositioning: identifying and developing new uses for existing drugs. Nature reviews Drug discovery 2004, 3, 673-683.

27. Dudley, J. T.; Deshpande, T.; Butte, A. J., Exploiting drug-disease relationships for computational drug repositioning. Briefings in bioinformatics 2011, 12, 303-311.

28. Tutumlu G, Dogan B, Avsar T, Orhan MD, Calis S, Durdagi S. Integrating Ligand and Target-Driven Based Virtual Screening Approaches with in vitro human Cell Line Models to Identify Novel Hit Compounds Against BCL-2. Frontiers in Chemistry 2020, DOI: $10.3389 /$ fchem.2020.00167

29. Ikram S, Ahmad J, Durdagi S. Screening of FDA approved drugs for finding potential inhibitor for Granzyme B as a potent drug-repurposing target. Journal of Molecular Graphics and Modeling 2020. DOI: 10.1016/j.jmgm.2019.107462.

30. Kanan T, Kanan D, Erol I, Yazdi S, Stein M, Durdagi S. Targeting the NF- $\kappa \mathrm{B} / \mathrm{I} \kappa \mathrm{B} \alpha$ Complex via Fragment-Based E-Pharmacophore Virtual Screening and Binary QSAR Models. Journal of Molecular Graphics and Modelling 2019, 86, 264-277.

31. Is YS, Durdagi S, Aksoydan B, Yurtsever M. Proposing Novel MAO-B Hit Inhibitors Using Multidimensional Molecular Modeling Approaches and Application of Binary QSAR Models for Prediction of their Therapeutic Activity and Toxic Effects. ACS Chemical Neuroscience 2018, 9(7), 1768-1782.

32. Durdagi S, Aksoydan B, Erol I, Kantarcioglu I, Ergun Y, Bulut G, Acar M, Avsar T, Liapakis G, Karageorgos V, Salmas RE, Sergi B, Alkhatib S, Turan G, Yigit BF, Cantasir K, Kurt B, Kilic T. Integration of Multi-scale Molecular Modeling Approaches with Experiments for the in silico Guided Design and Discovery of Novel hERG-Neutral 
Antihypertensive Oxazalone and Imidazolone Derivatives and Analysis of Their Potential Restrictive Effects on Cell Proliferation. European Journal of Medicinal Chemistry 2018;145:273-290

33. Shoichet, B. K.; McGovern, S. L.; Wei, B.; Irwin, J. J., Lead discovery using molecular docking. Current opinion in chemical biology 2002, 6, 439-446.

34. Chen, L.; Gui, C.; Luo, X.; Yang, Q.; Günther, S.; Scandella, E.; Drosten, C.; Bai, D.; $\mathrm{He}, \mathrm{X}$.; Ludewig, B., Cinanserin is an inhibitor of the $3 \mathrm{C}$-like proteinase of severe acute respiratory syndrome coronavirus and strongly reduces virus replication in vitro. Journal of virology 2005, 79, 7095-7103.

35. Liu, Z.; Huang, C.; Fan, K.; Wei, P.; Chen, H.; Liu, S.; Pei, J.; Shi, L.; Li, B.; Yang, K., Virtual screening of novel noncovalent inhibitors for SARS-CoV 3C-like proteinase. Journal of chemical information and modeling 2005, 45, 10-17.

36. Wishart, D. S.; Feunang, Y. D.; Guo, A. C.; Lo, E. J.; Marcu, A.; Grant, J. R.; Sajed, T.; Johnson, D.; Li, C.; Sayeeda, Z., DrugBank 5.0: a major update to the DrugBank database for 2018. Nucleic acids research 2018, 46, D1074-D1082.

37. Li, Y.; Zhang, J.; Wang, N.; Li, H.; Shi, Y.; Guo, G.; Liu, K.; Zeng, H.; Zou, Q., Therapeutic Drugs Targeting 2019-nCoV Main Protease by High-Throughput Screening. bioRxiv 2020.

38. Labbé, C. M.; Rey, J.; Lagorce, D.; Vavruša, M.; Becot, J.; Sperandio, O.; Villoutreix, B. O.; Tufféry, P.; Miteva, M. A., MTiOpenScreen: a web server for structure-based virtual screening. Nucleic acids research 2015, 43, W448-W454.

39. Trott, O.; Olson, A. J., AutoDock Vina: improving the speed and accuracy of docking with a new scoring function, efficient optimization, and multithreading. Journal of computational chemistry 2010, 31, 455-461.

40. Jin, Z.; Du, X.; Xu, Y.; Deng, Y.; Liu, M.; Zhao, Y.; Zhang, B.; Li, X.; Zhang, L.; Duan, Y., Structure-based drug design, virtual screening and high-throughput screening rapidly identify antiviral leads targeting COVID-19. bioRxiv 2020.

41. Evans DJ; Holian BL. The Nose-Hoover thermostat. J. Chem. Phys. 83, 4069 (1985); DOI: $10.1063 / 1.449071$

42. Martyna GJ, Tobias DJ, Klein ML. Constant pressure molecular dynamics algorithms. J. Chem. Phys. 1994, 101 (5),4177. 


\section{Tables}

Table 1. Selected hit compounds based on average MM/GBSA scores from short (10-ns) MD simulations. Long (100-ns) MD simulations are performed for these identified hits and average MM/GBSA scores were calculated using 1000-trajectory frames throughout the simulations. Table also shows the corresponding mechanism of actions of the identified compounds.

\begin{tabular}{|c|c|c|c|}
\hline Compounds & 2D Structures & $\begin{array}{l}\text { MM/GBSA } \\
\text { (kcal/mol) }\end{array}$ & Mechanism of Action \\
\hline Rotigaptide & & -86.81 & $\begin{array}{l}\text { Rotigaptide (ZP-123) is a drug under } \\
\text { clinical investigation for the } \\
\text { treatment of cardiac arrhythmias - } \\
\text { specifically atrial fibrillation. }\end{array}$ \\
\hline Lasinavir & & -80.59 & HIV Protease inhibitor \\
\hline Pimelautide & & -76.17 & $\begin{array}{l}\text { Immunostimulant. Pimelautide Built- } \\
\text { in Adjuvants Associated with an HIV- } \\
\text { 1-Derived Peptide }\end{array}$ \\
\hline $\begin{array}{l}\text { 1,3-Bis-(2- } \\
\text { ethoxycarbonylchromon-5- } \\
\text { yloxy)-2-(lysyloxy)propane }\end{array}$ & & -75.59 & $\begin{array}{l}\text { Orally-active pro-drug of disodium } \\
\text { cromoglycate (DSCG). DSCG is a } \\
\text { commonly used anti-asthmatic } \\
\text { medicine }\end{array}$ \\
\hline Telinavir & & -74.22 & HIV Protease inhibitor \\
\hline Brecanavir & & -74.06 & $\begin{array}{l}\text { Aspartic protease inhibitor for the } \\
\text { treatment of HIV }\end{array}$ \\
\hline
\end{tabular}




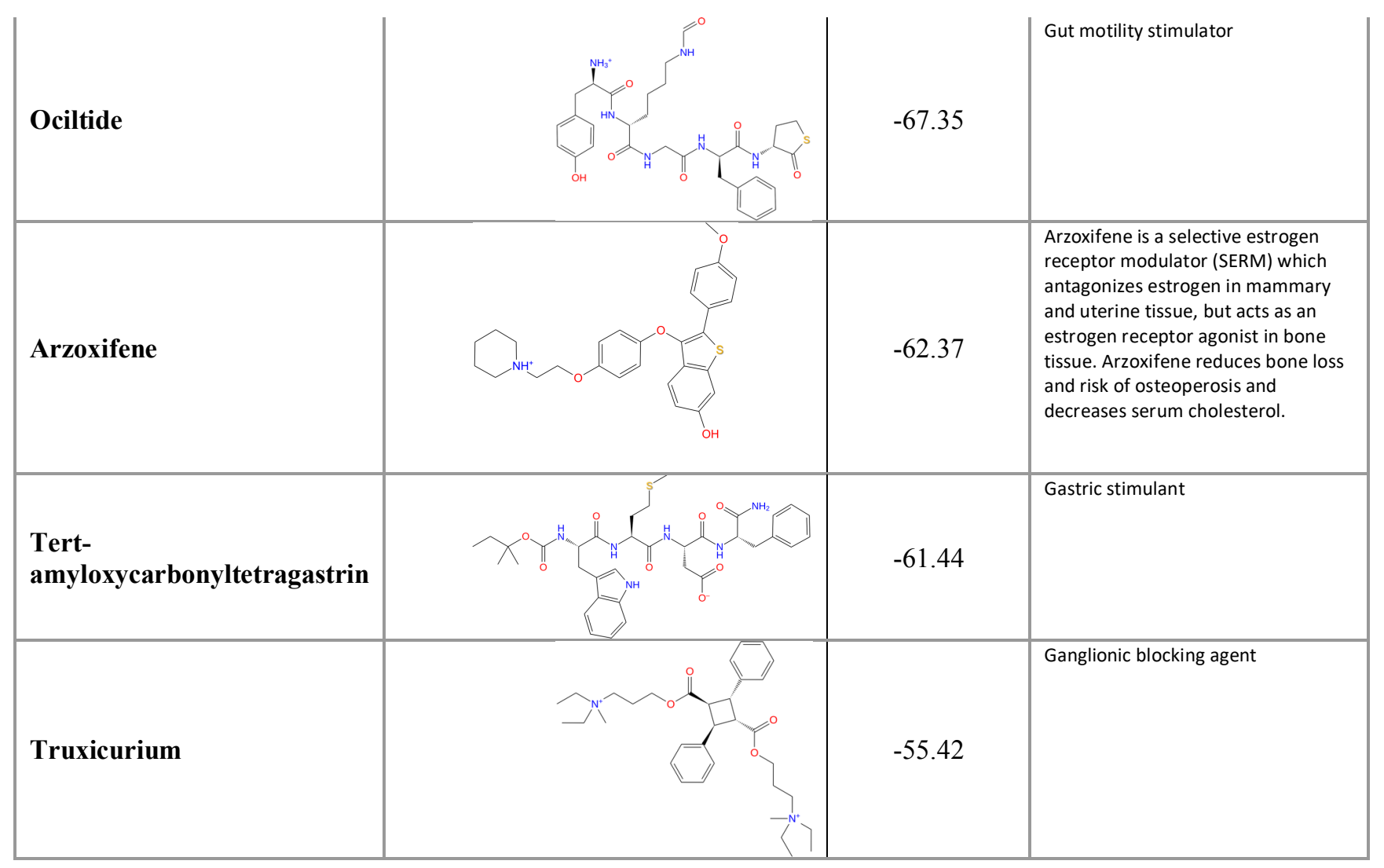



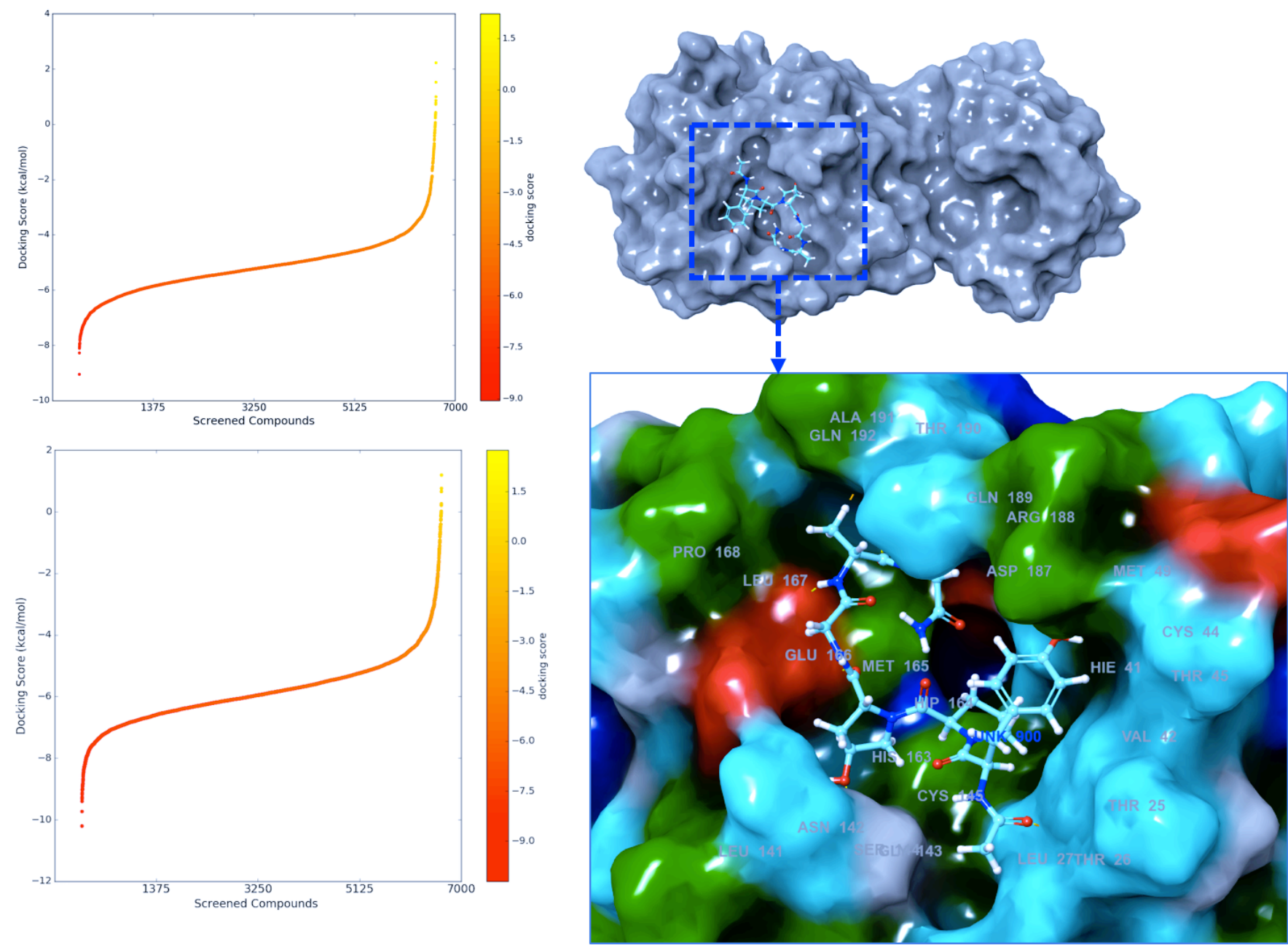

Figure 1. Around 7000 FDA approved and drugs in clinical investigation from NPC database were screened at the apo (top-left) and holo (bottomleft) COVID-19 Main Protease target. Hierarchical hybrid screening constructed by our group led to 6 hit compounds. Surface representation of one the identified hit compound Rotigaptide has been shown in right. 


\section{Supplementary Materials}

\section{Screening of Clinically Approved and Investigation Drugs as Potential Inhibitors of COVID-19 Main Protease: A Virtual Drug Repurposing Study}

Serdar Durdagi ${ }^{1, *}$, Busecan Aksoydan ${ }^{1,2}$, Berna Dogan ${ }^{1}, \operatorname{Kader~Sahin~}^{1}$, Aida Shahraki ${ }^{1,3}$

${ }^{1}$ Computational Biology and Molecular Simulations Laboratory, Department of Biophysics, School of Medicine, Bahcesehir University, Istanbul, Turkey

${ }^{2}$ Neuroscience Program, Graduate School of Health Sciences, Bahçeşehir University, Istanbul, Turkey ${ }^{3}$ Department of Molecular Biology and Genetics, Bogazici University, Istanbul, Turkey 
Table S1. Top-100 compounds at the binding pocket of COVID-19 Main Protease crystallized in holo-form (PDB, 6LU7) based on Glide/SP docking scores and their corresponding docking scores.

\begin{tabular}{|c|c|}
\hline Compounds & $\begin{array}{l}\text { docking } \\
\text { score } \\
\text { (kcal/mol) }\end{array}$ \\
\hline Truxipicurium iodide & -10.209 \\
\hline Ametantrone & -9.736 \\
\hline Arzoxifene & -9.405 \\
\hline Tert-amyloxycarbonyltetragastrin & -9.324 \\
\hline mitoxantrone & -9.270 \\
\hline Ingliforib & -9.178 \\
\hline Frakefamide & -9.134 \\
\hline Pimelautide & -9.041 \\
\hline Truxicurium & -9.026 \\
\hline Rotigaptide & -9.009 \\
\hline Metkephamid & -8.998 \\
\hline $\begin{array}{l}\text { 1,3-Bis-(2-ethoxycarbonylchromon-5-yloxy)-2- } \\
\text { (lysyloxy)propane }\end{array}$ & -8.926 \\
\hline Mioflazinum & -8.913 \\
\hline Telinavir & -8.903 \\
\hline Alvimopan & -8.899 \\
\hline Ociltide & -8.896 \\
\hline Azimilide & -8.856 \\
\hline Penimepicycline & -8.839 \\
\hline flupenthixol & -8.817 \\
\hline loglucol & -8.748 \\
\hline Prezatidicupriciacetas & -8.721 \\
\hline Bazedoxifene & -8.701 \\
\hline Losoxantrone & -8.684 \\
\hline Brecanavir & -8.678 \\
\hline Xantifibrate & -8.598 \\
\hline Diathymosulfonum & -8.548 \\
\hline Ledoxantrone & -8.512 \\
\hline Carafiban & -8.476 \\
\hline Efegatran & -8.461 \\
\hline Iohexol & -8.448 \\
\hline Pipendoxifene & -8.447 \\
\hline Sampatrilat & -8.437 \\
\hline Bialamicol & -8.404 \\
\hline Pinoxepin & -8.394 \\
\hline Demecariumbromide & -8.391 \\
\hline Teloxantrone & -8.373 \\
\hline
\end{tabular}




\begin{tabular}{|c|c|}
\hline Tetragastrin & -8.352 \\
\hline Bms181176-14 & -8.338 \\
\hline Utibapril & -8.301 \\
\hline$Z y-15051$ & -8.292 \\
\hline Epicainide & -8.291 \\
\hline Genestein & -8.289 \\
\hline Aspoxicillin & -8.289 \\
\hline Ftorpropazine & -8.286 \\
\hline $\begin{array}{l}\text { 14-Benzodioxin-2-methanolalphaalpha'- } \\
\text { (iminobis(methylene))bis(2 3-dihydro)- } \\
\text { stereoisomer methanesulfonate }\end{array}$ & -8.283 \\
\hline Bisnafide & -8.282 \\
\hline Flutiazin & -8.274 \\
\hline Etanterol & -8.270 \\
\hline Mefloquine & -8.269 \\
\hline Proflazepam & -8.263 \\
\hline Imidazolidinylureamonosodium & -8.256 \\
\hline ritonavir & -8.226 \\
\hline Montirelin & -8.223 \\
\hline Lu-79553 & -8.220 \\
\hline Osutidine & -8.204 \\
\hline R1634 & -8.204 \\
\hline Pinokalant & -8.196 \\
\hline Piroxantrone & -8.184 \\
\hline Reproterol & -8.175 \\
\hline Tigecycline & -8.165 \\
\hline Alatrofloxacin & -8.145 \\
\hline Carbuterol & -8.138 \\
\hline Ibutamoren & -8.136 \\
\hline Solabegron & -8.124 \\
\hline Benzilonium & -8.121 \\
\hline Nofecainide & -8.121 \\
\hline Spiclomazinum & -8.094 \\
\hline Lopinavir & -8.083 \\
\hline Topixantrone & -8.081 \\
\hline taltirelin & -8.080 \\
\hline Terlakiren & -8.068 \\
\hline Rolitetracycline & -8.056 \\
\hline Asimadoline & -8.053 \\
\hline Lasinavir & -8.051 \\
\hline lopamidol & -8.043 \\
\hline Cilengitide & -8.039 \\
\hline Pixantrone & -8.023 \\
\hline
\end{tabular}




\begin{tabular}{|l|c|}
\hline Bamifylline & -8.010 \\
\hline $\begin{array}{l}\text { 2-Chloro-9-(3-dimethylaminopropyl)-9h- } \\
\text { thioxanthen-9-ol }\end{array}$ & -8.003 \\
\hline Remikiren & -8.003 \\
\hline Fludazoniumchloride & -7.997 \\
\hline Pd-196860 & -7.994 \\
\hline Butocrolol & -7.993 \\
\hline loversol & -7.963 \\
\hline 5-(1-Methyl-4-piperidyl)-5h- & -7.963 \\
\hline dibenzo[ad]cyclohepten-5-olhydrochloride & -7.952 \\
\hline loxilan & -7.950 \\
\hline Glufosfamide & -7.947 \\
\hline Moditenenanthate & -7.945 \\
\hline posaconazole & -7.938 \\
\hline 2-[Benzyl(tert-butyl)amino]-1-(a4-dihydroxy-m- & \\
\hline tolyl)ethanol & -7.934 \\
\hline Alpiropride & -7.933 \\
\hline Flecainide & -7.932 \\
\hline Ambamustine & -7.932 \\
\hline Ra-233 & -7.931 \\
\hline amisulpride & -7.930 \\
\hline Rebimastat & -7.927 \\
\hline Flestolol & -7.921 \\
\hline Capromorelin & -7.917 \\
\hline Difluaninehydrochloride & -7.909 \\
\hline Ecopladib & \\
\hline
\end{tabular}


Table S2. Top-100 compounds at the binding pocket of COVID-19 Main Protease crystallized in apo-form (PDB, 6M03) based on Glide/SP docking scores and their corresponding docking scores.

\begin{tabular}{|c|c|}
\hline Compounds & $\begin{array}{l}\text { docking } \\
\text { score } \\
\text { (kcal/mol) }\end{array}$ \\
\hline Ametantrone & -9.211 \\
\hline Teloxantrone & -9.053 \\
\hline mitoxantrone & -8.279 \\
\hline Rotigaptide & -8.113 \\
\hline Pixantrone & -8.065 \\
\hline $\begin{array}{l}\text { 2-(3,4-Dihydroxyphenyl)-3,5,7-trihydroxy-4h- } \\
\text { chromen-4-one }\end{array}$ & -8.038 \\
\hline 5,7,3,4-Tetrahydroxyflavan-3'4'-diol & -7.976 \\
\hline losericacid & -7.965 \\
\hline Emiglitate & -7.942 \\
\hline Prospidiumchloride & -7.938 \\
\hline Etanterol & -7.920 \\
\hline loglunide & -7.824 \\
\hline Olmidinehydrochloride (-)-isomer & -7.782 \\
\hline Sibrafiban & -7.763 \\
\hline Fluprostenol & -7.730 \\
\hline Chrysarobin & -7.726 \\
\hline Osutidine & -7.706 \\
\hline $\begin{array}{l}\text { Benzyl(tert-butyl)(4-hydroxy-3-hydroxymethyl-4- } \\
\text { oxophenethyl) ammonium chloride }\end{array}$ & -7.687 \\
\hline Cefapirin & -7.685 \\
\hline Difebarbamate & -7.680 \\
\hline Donitriptan & -7.653 \\
\hline Ioxilan & -7.649 \\
\hline Losoxantrone & -7.645 \\
\hline Lasinavir & -7.635 \\
\hline Ociltide & -7.633 \\
\hline Isatoribine & -7.613 \\
\hline Lu-79553 & -7.603 \\
\hline Nepafenac & -7.601 \\
\hline Cantabiline & -7.595 \\
\hline Pd-196860 & -7.586 \\
\hline Clopenthixol & -7.571 \\
\hline lotriside & -7.570 \\
\hline Netivudine & -7.565 \\
\hline Toldimfos & -7.564 \\
\hline Adosopine & -7.563 \\
\hline Difluaninehydrochloride & -7.536 \\
\hline
\end{tabular}




\begin{tabular}{|c|c|}
\hline Emivirine & -7.530 \\
\hline Cifostodine & -7.510 \\
\hline Fenprostalene & -7.488 \\
\hline Dinoprost & -7.487 \\
\hline Reproterol & -7.481 \\
\hline Beta-d-glucopyranoside-4-hydroxyphenyl & -7.464 \\
\hline $\begin{array}{l}\text { 5-Chloro-1-(4-(4,4-bis(p-fluorophenyl)butyl)-4- } \\
\text { piperidyl)-2-benzimidazolinone }\end{array}$ & -7.459 \\
\hline Orotirelin & -7.451 \\
\hline Prezatidicuprici acetas & -7.451 \\
\hline cladribine & -7.447 \\
\hline Vesnarinone & -7.439 \\
\hline Carboprost & -7.432 \\
\hline arformoterol & -7.431 \\
\hline Tusigen & -7.420 \\
\hline Primozida & -7.418 \\
\hline Enprostil & -7.416 \\
\hline Nordefrin & -7.396 \\
\hline D-glycero-D-gulo-Heptonicacid & -7.390 \\
\hline Fenoterol & -7.384 \\
\hline Torbafylline & -7.382 \\
\hline Doreptide & -7.381 \\
\hline Tilisolol & -7.361 \\
\hline Lobucavir & -7.361 \\
\hline Ilomastat & -7.349 \\
\hline Eganoprost & -7.348 \\
\hline Eplivanserin & -7.338 \\
\hline $\begin{array}{l}\text { (1R2R)-2-amino-1-(4- } \\
\text { methylsulfonylphenyl)propane-1 3-diol }\end{array}$ & -7.332 \\
\hline Sapropterin & -7.331 \\
\hline Odiparcilum & -7.328 \\
\hline Arabinosylthymine & -7.325 \\
\hline Cicarperone & -7.323 \\
\hline Tetragastrin & -7.312 \\
\hline Iohexol & -7.299 \\
\hline Telinavir & -7.297 \\
\hline Nofecainide & -7.291 \\
\hline Prostalene & -7.282 \\
\hline Lasofoxifene & -7.279 \\
\hline Spasfon-lyoc & -7.277 \\
\hline Cefradine & -7.275 \\
\hline Resorcinoldisodium & -7.271 \\
\hline Tiaprost & -7.267 \\
\hline
\end{tabular}




\begin{tabular}{|l|c|}
\hline $\begin{array}{l}\text { 1,4-Benzodioxin-2-methanolalpha alpha'- } \\
\text { (iminobis(methylene))bis(2 3-dihydro)- } \\
\text { stereoisomer methanesulfonate }\end{array}$ \\
\hline Fidarestat & -7.258 \\
\hline Temoporfin & -7.255 \\
\hline Glucosulfamide & -7.254 \\
\hline cefotiam & -7.251 \\
\hline Maribavir & -7.251 \\
\hline Sulprostone & -7.248 \\
\hline 1,3-Bis-(2-ethoxycarbonylchromon-5-yloxy)-2- & -7.243 \\
\hline (lysyloxy)propane & -7.241 \\
\hline Iliparcil & -7.238 \\
\hline Zy-15051 & -7.237 \\
\hline Adenosine & -7.228 \\
\hline Ibutamoren & -7.225 \\
\hline Beciparcil & -7.216 \\
\hline Tigecycline & -7.215 \\
\hline Midodrine & -7.204 \\
\hline Cefpiramide & -7.201 \\
\hline Cefetecol & -7.196 \\
\hline Soquinolol & -7.194 \\
\hline Mioflazinum & -7.193 \\
\hline Ceforanide & -7.193 \\
\hline Carafiban & -7.186 \\
\hline Piroxantrone & -7.186 \\
\hline Eptaplatin & -7.171 \\
\hline
\end{tabular}


Table S3. Average binding free energies (MM/GBSA scores) of selected top-30 compounds from docking at the COVID-19 Main protease crystallized in holo form. 1000 trajectory frames were considered throughout the short (10-ns) MD simulations.

\begin{tabular}{|c|c|}
\hline Compounds & $\begin{array}{l}\mathrm{MM} / \mathrm{GBSA} \\
\text { (kcal/mol) }\end{array}$ \\
\hline Pimelautide & -83.71 \\
\hline Rotigaptide & -81.21 \\
\hline Truxicurium & -78.58 \\
\hline Tert-amyloxycarbonyltetragastrin & -76.71 \\
\hline $\begin{array}{l}\text { 1,3-Bis-(2-ethoxycarbonylchromon-5-yloxy)-2- } \\
\text { (lysyloxy)propane }\end{array}$ & -76.59 \\
\hline Brecanavir & -74.83 \\
\hline Arzoxifene & -74.35 \\
\hline Ociltide & -74.30 \\
\hline Telinavir & -70.13 \\
\hline Frakefamide & -67.54 \\
\hline Truxipicurium iodide & -67.38 \\
\hline Carafiban & -67.26 \\
\hline Metkephamid & -61.33 \\
\hline Diathymosulfonum & -60.84 \\
\hline Penimepicycline & -60.76 \\
\hline Mioflazinum & -59.03 \\
\hline Ingliforib & -55.04 \\
\hline Azimilide & -54.68 \\
\hline Efegatran & -54.26 \\
\hline Ioglucol & -52.63 \\
\hline mitoxantrone & -50.13 \\
\hline Prezatidicupriciacetas & -48.56 \\
\hline Iohexol & -48.18 \\
\hline Ametantrone & -47.57 \\
\hline Alvimopan & -47.57 \\
\hline flupenthixol & -47.37 \\
\hline Bazedoxifene & -37.85 \\
\hline Losoxantrone & -36.40 \\
\hline Ledoxantrone & -32.26 \\
\hline Xantifibrate & -32.19 \\
\hline
\end{tabular}


Table S4. Average binding free energies (MM/GBSA scores) of selected top-30 compounds from docking at the COVID-19 Main protease crystallized in apo form. 1000 trajectory frames were considered throughout the short (10-ns) MD simulations.

\begin{tabular}{|c|c|}
\hline Compounds & $\begin{array}{l}\mathrm{MM} / \mathrm{GBSA} \\
\text { (kcal/mol) }\end{array}$ \\
\hline Lasinavir & -73.58 \\
\hline loglunide & -67.04 \\
\hline Osutidine & -64.55 \\
\hline Ociltide & -63.79 \\
\hline Ioxilan & -61.83 \\
\hline Emiglitate & -60.12 \\
\hline Ametantrone & -59.64 \\
\hline losericacid & -59.38 \\
\hline Fluprostenol & -58.18 \\
\hline Difebarbamate & -56.78 \\
\hline mitoxantrone & -55.08 \\
\hline $\begin{array}{l}\text { Benzyl(tert-butyl)(4-hydroxy-3-hydroxymethyl-4- } \\
\text { oxophenethyl) ammonium chloride }\end{array}$ & -51.21 \\
\hline $\begin{array}{l}\text { 2-(3,4-Dihydroxyphenyl)-3,5,7-trihydroxy-4h- } \\
\text { chromen-4-one }\end{array}$ & -50.08 \\
\hline Sibrafiban & -48.67 \\
\hline Losoxantrone & -48.67 \\
\hline Rotigaptide & -47.64 \\
\hline Lu-79553 & -46.52 \\
\hline Teloxantrone & -46.51 \\
\hline Donitriptan & -44.41 \\
\hline Etanterol & -42.35 \\
\hline Nepafenac & -40.44 \\
\hline Isatoribine & -38.91 \\
\hline Pixantrone & -36.58 \\
\hline Pd-196860 & -36.07 \\
\hline 5,7,3,4-Tetrahydroxyflavan-3'4'-diol & -35.96 \\
\hline Chrysarobin & -34.66 \\
\hline Cefapirin & -32.08 \\
\hline Prospidiumchloride & -28.81 \\
\hline Olmidinehydrochloride (-)-isomer & -27.91 \\
\hline Cantabiline & -17.45 \\
\hline
\end{tabular}



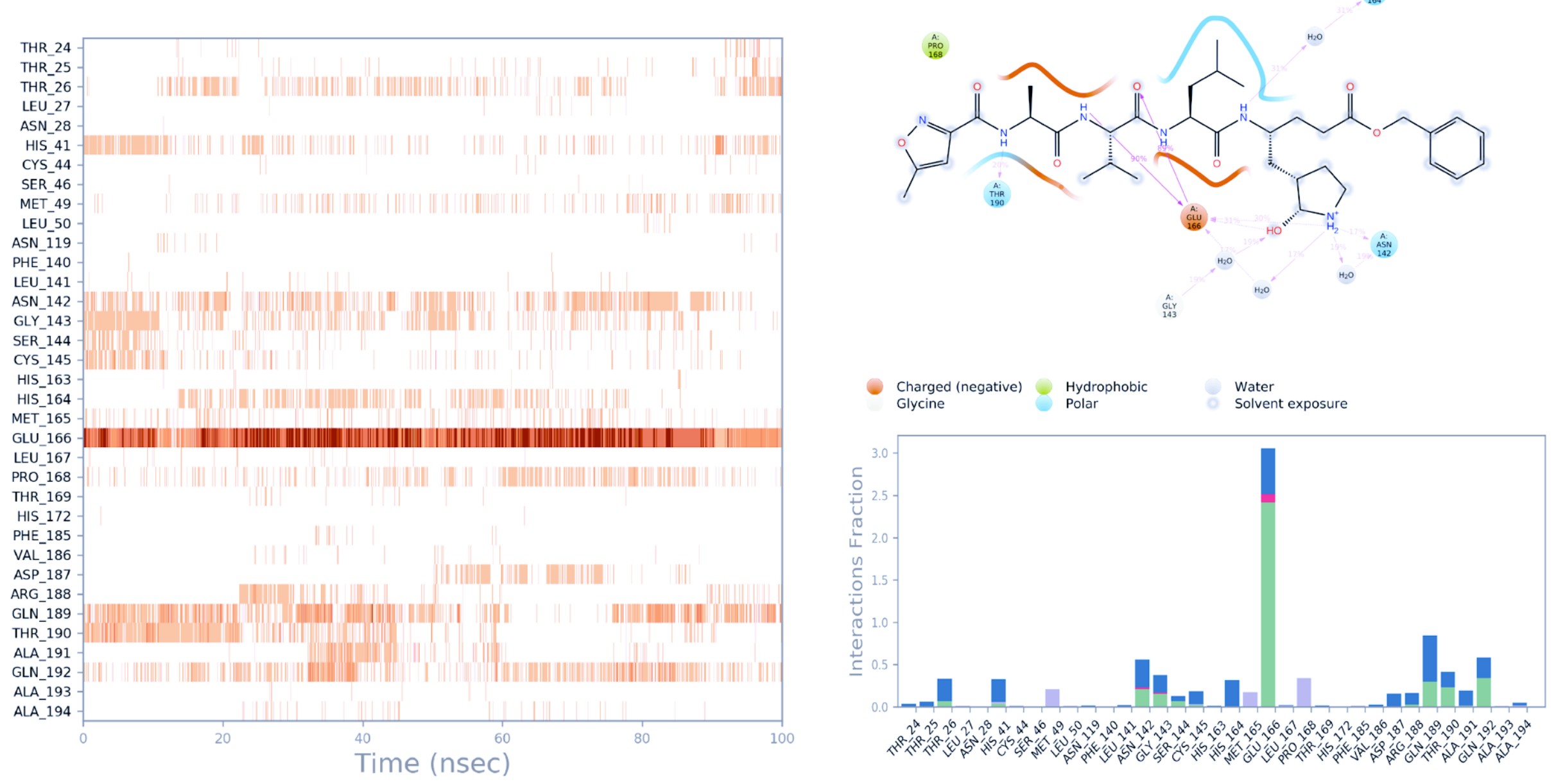

H-bonds Hydrophobic $\square$ lonic $\square$ Water bridges

Figure S1. Ligand interactions diagram for co-crystallized ligand N3. 

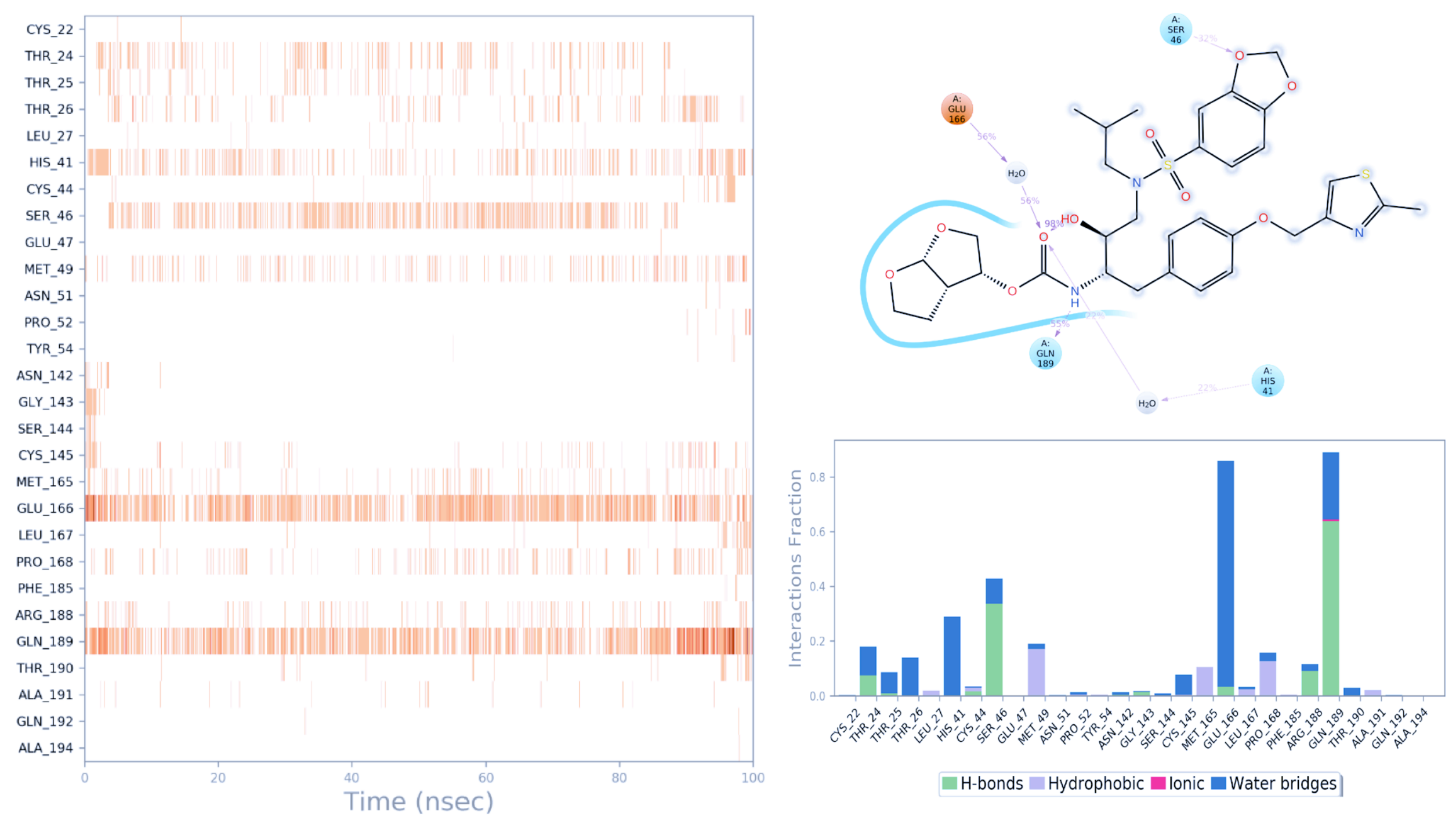

Figure S2. Ligand interactions diagram for Brecanavir 


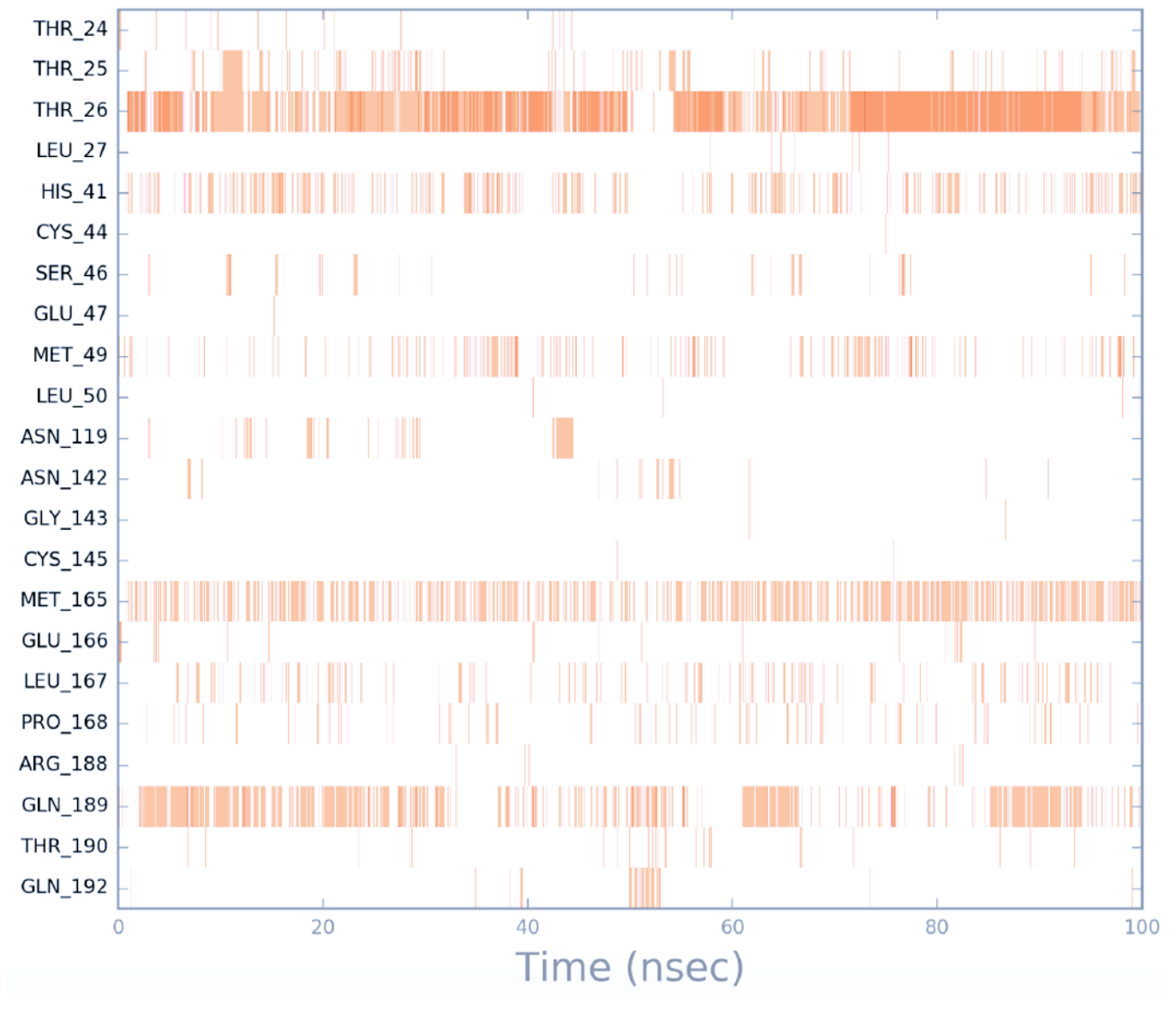

Figure S3. Ligand interactions diagram for Lasinavir

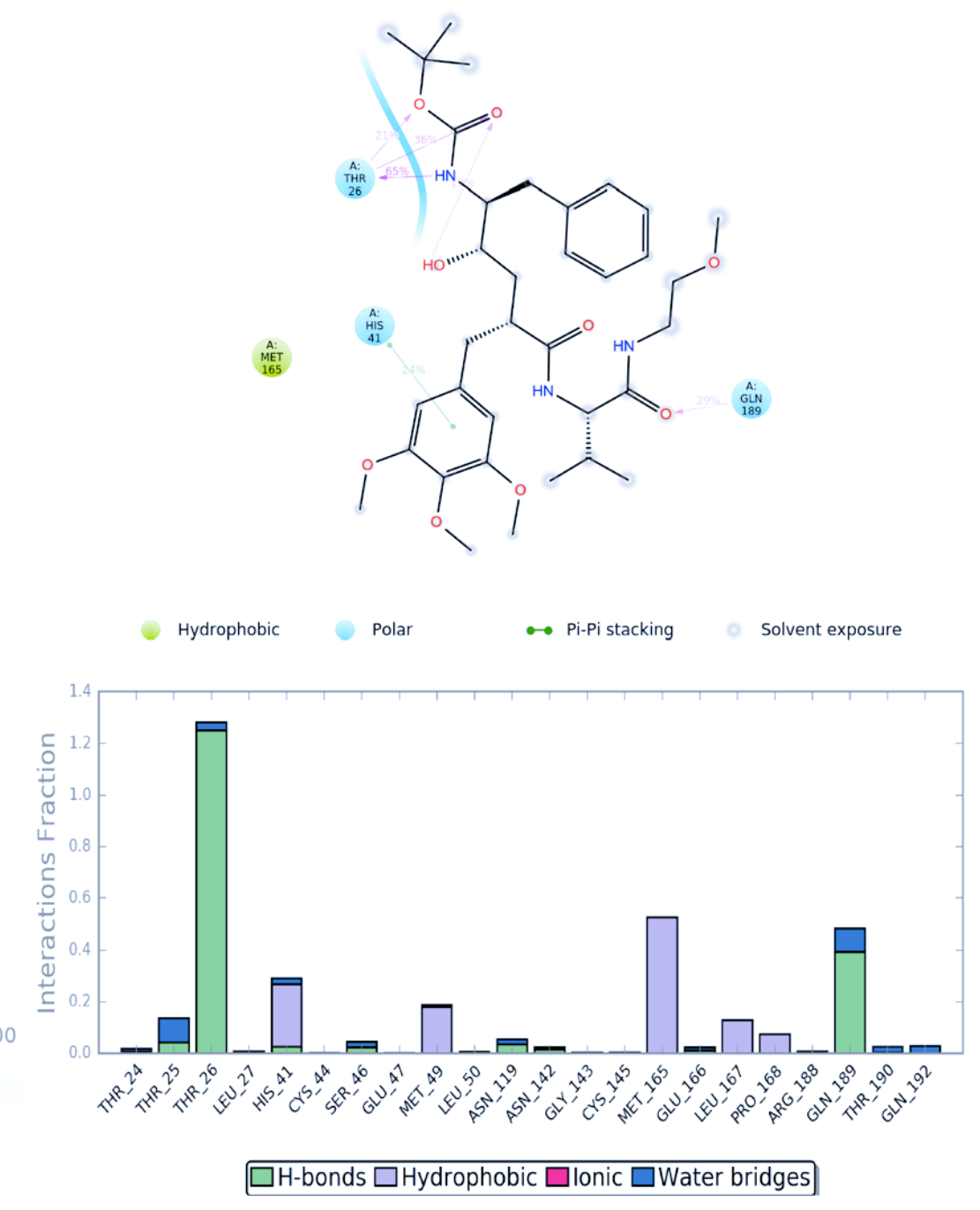

$\square$ H-bonds $\square$ Hydrophobic $\square$ lonic $\square$ Water bridges 


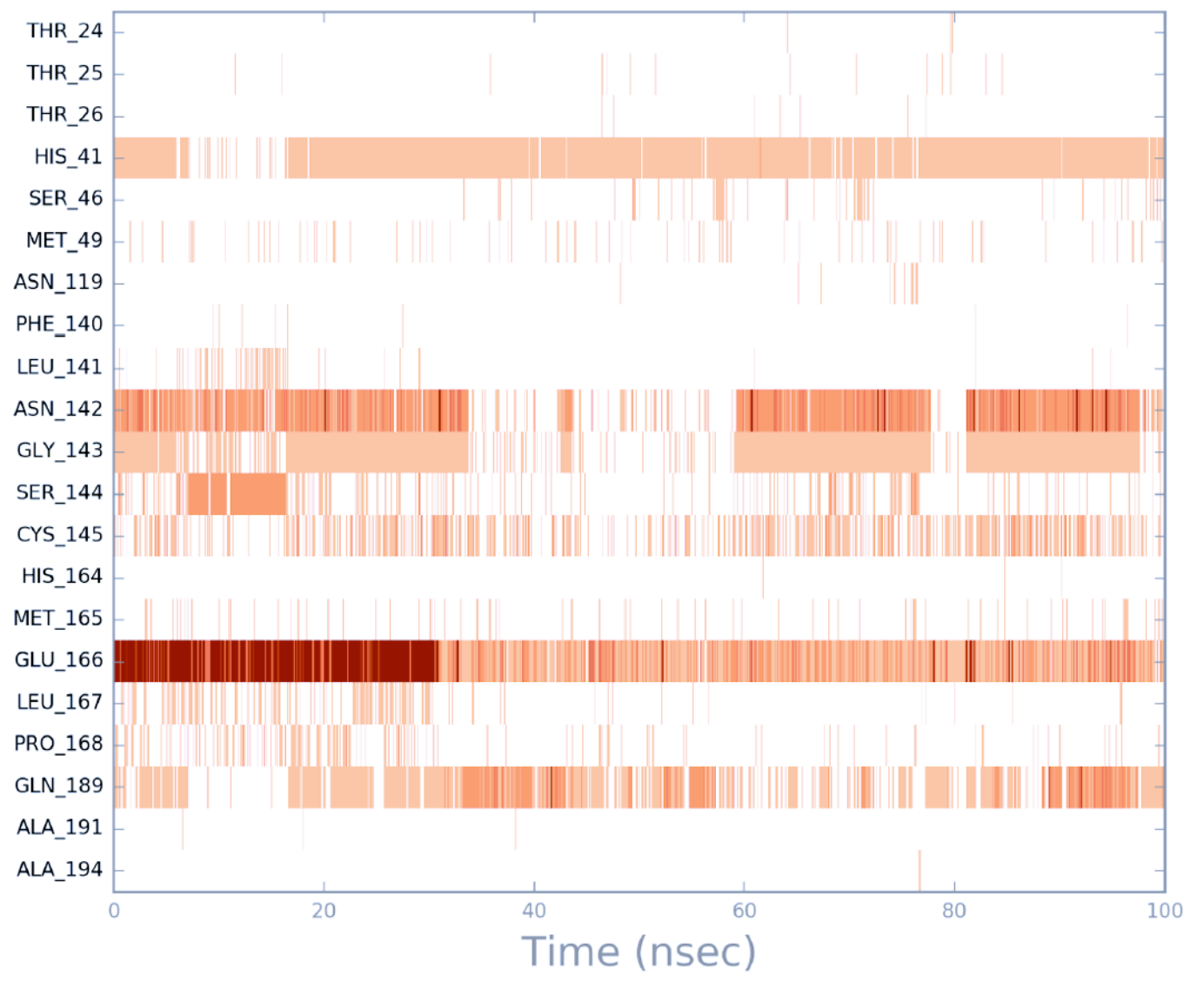

Figure S4. Ligand interactions diagram for Pimelautide

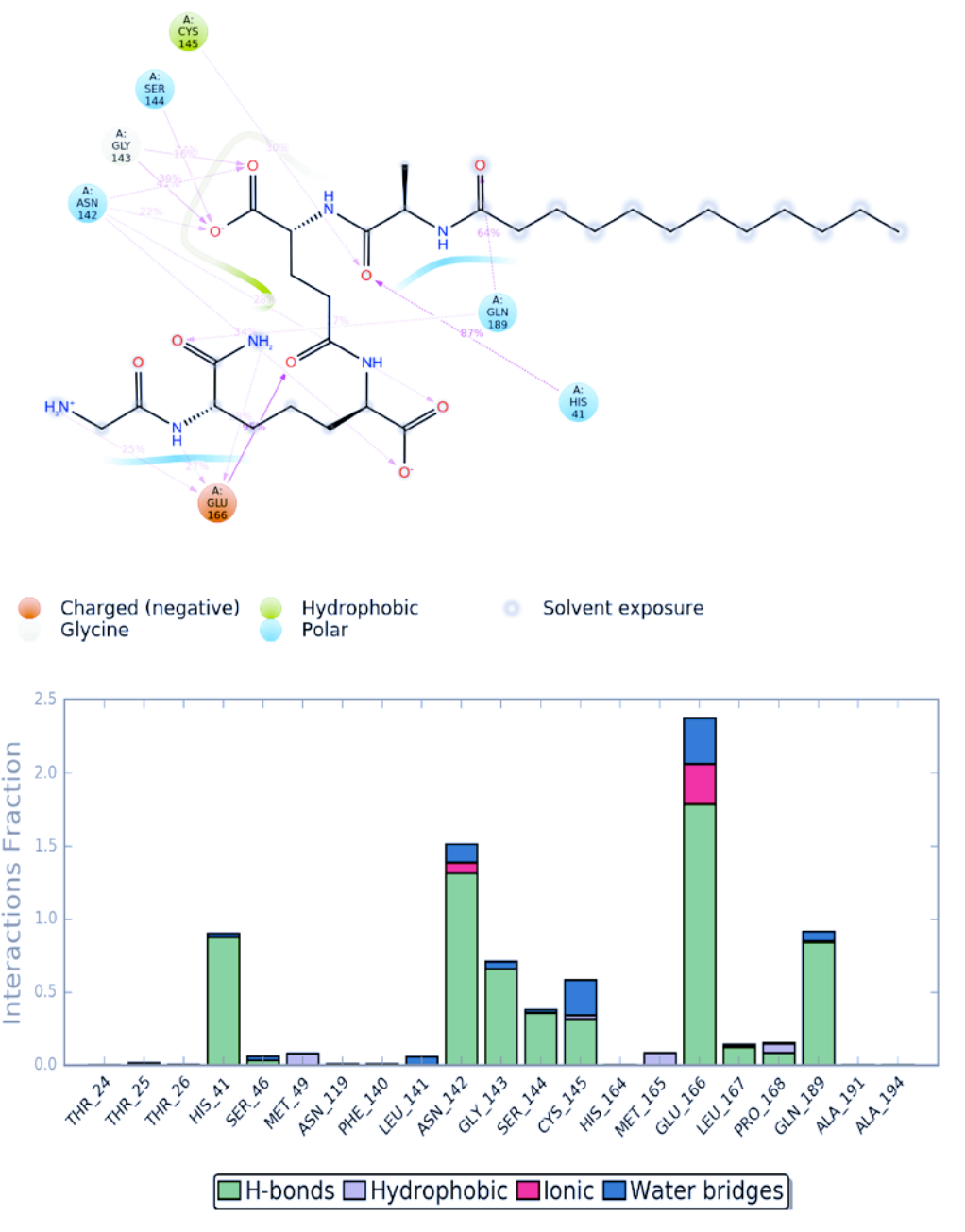

$\square$ H-bonds $\square$ Hydrophobic $\square$ lonic $\square$ Water bridges 

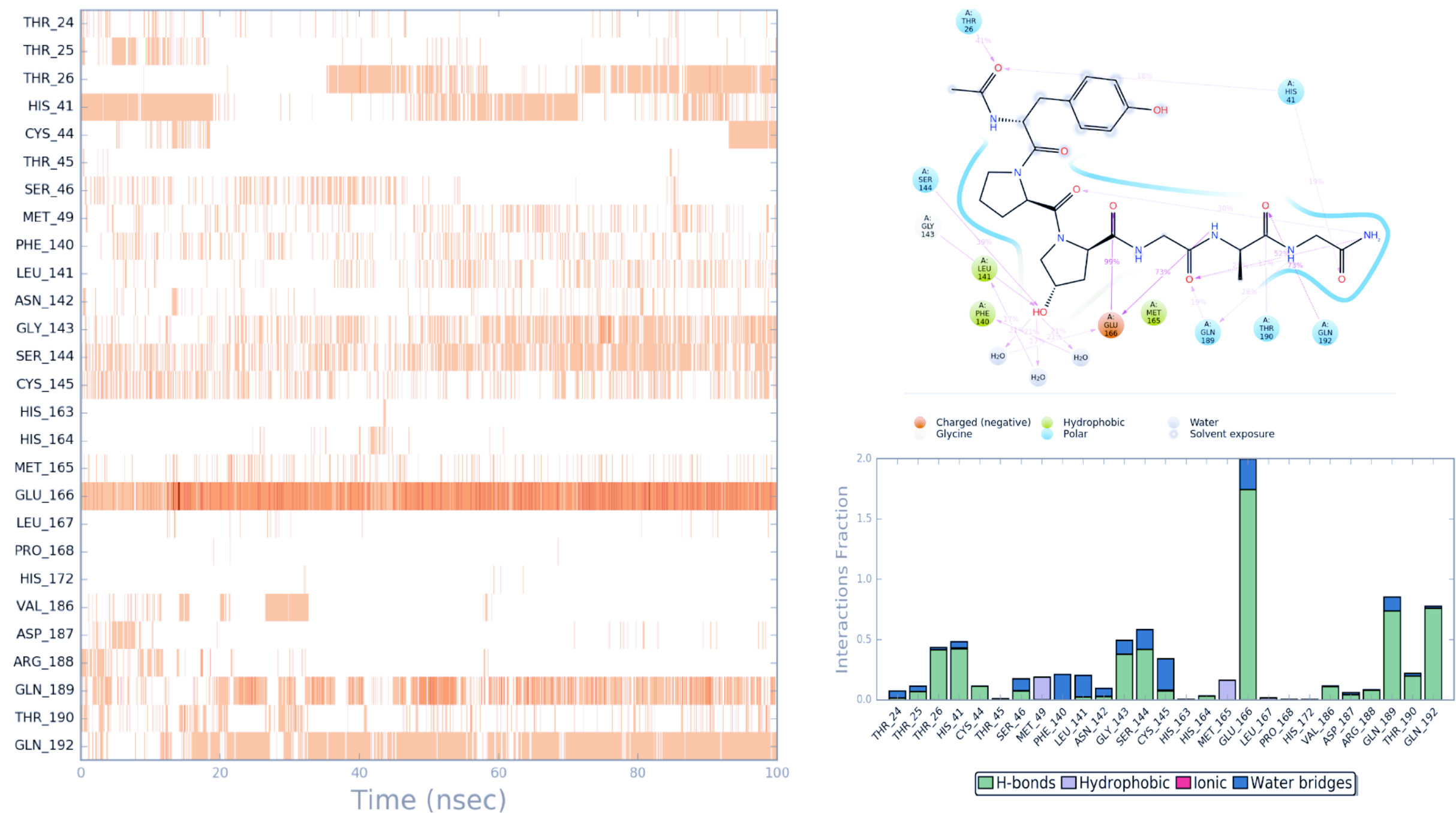

Figure S5. Ligand interactions diagram for Rotigaptide. 

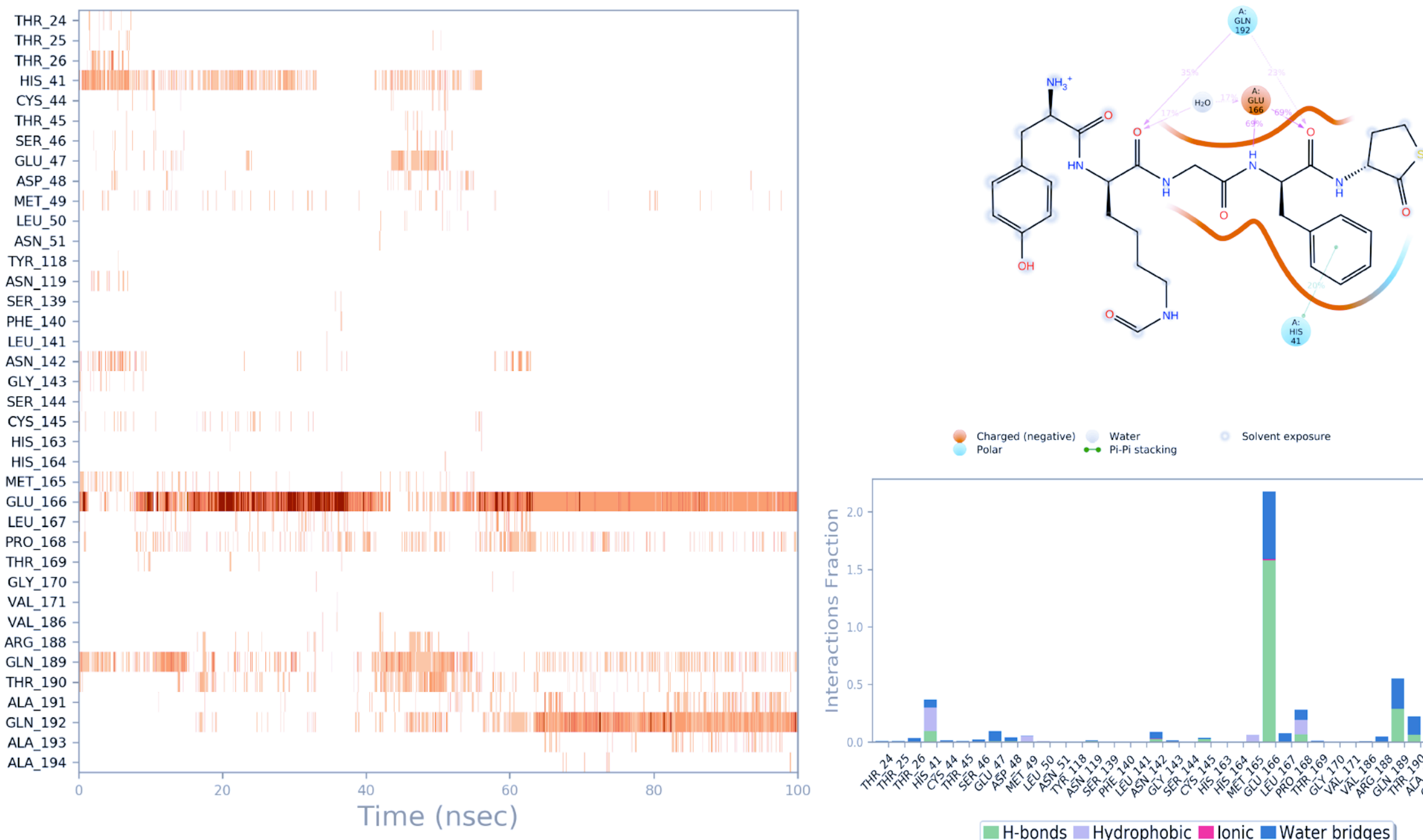

Charged (negative)
Polar

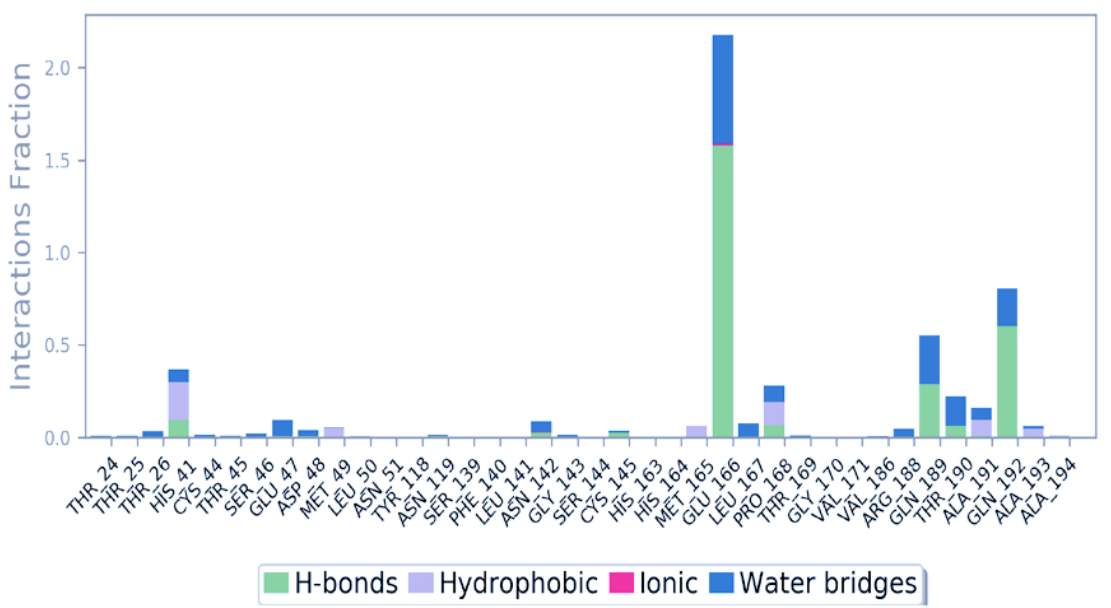

Figure S6. Ligand interactions diagram for Ociltide. 

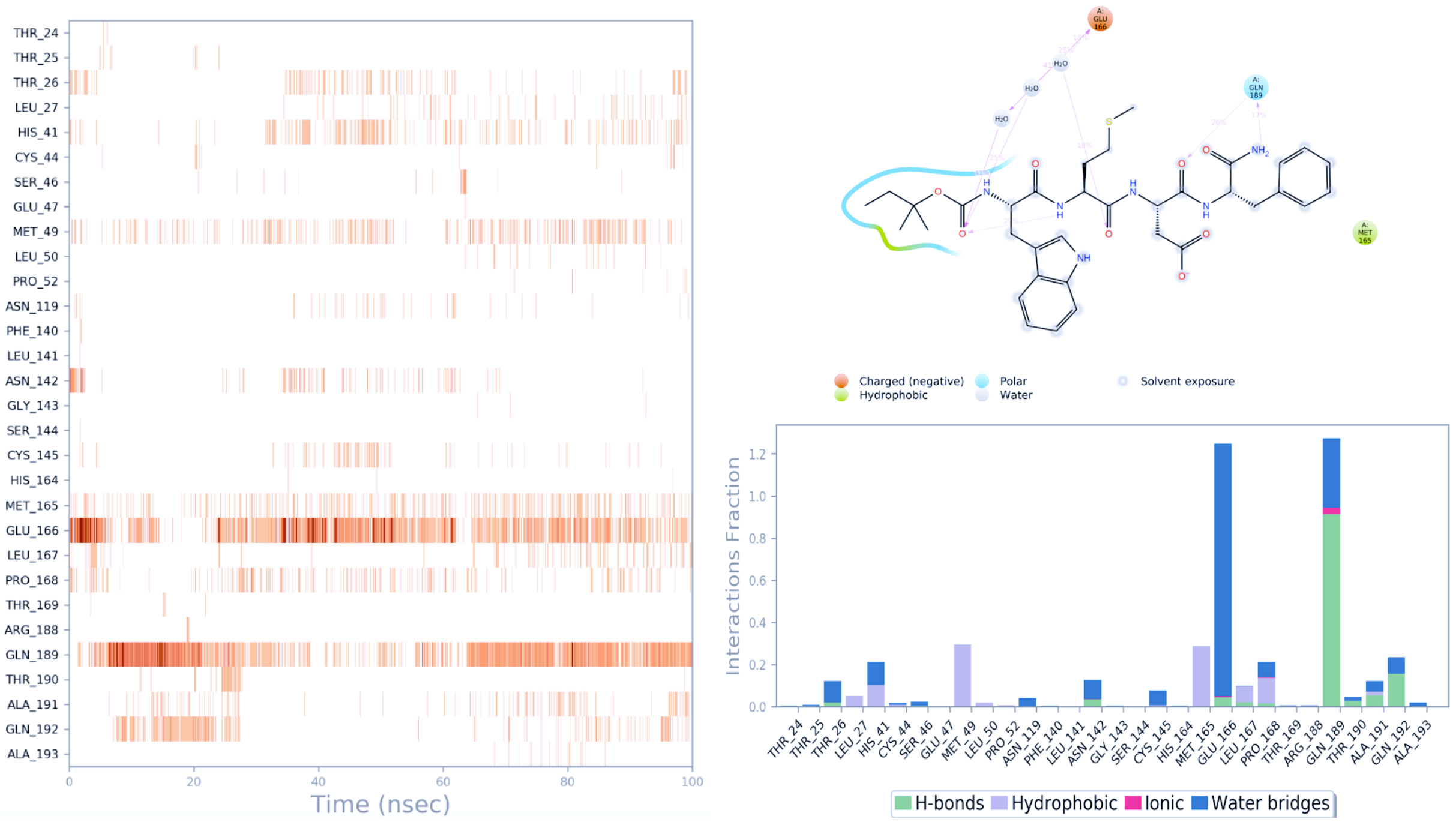

Figure S7. Ligand interactions diagram for tert-amyloxycarbonyltetragastrin 


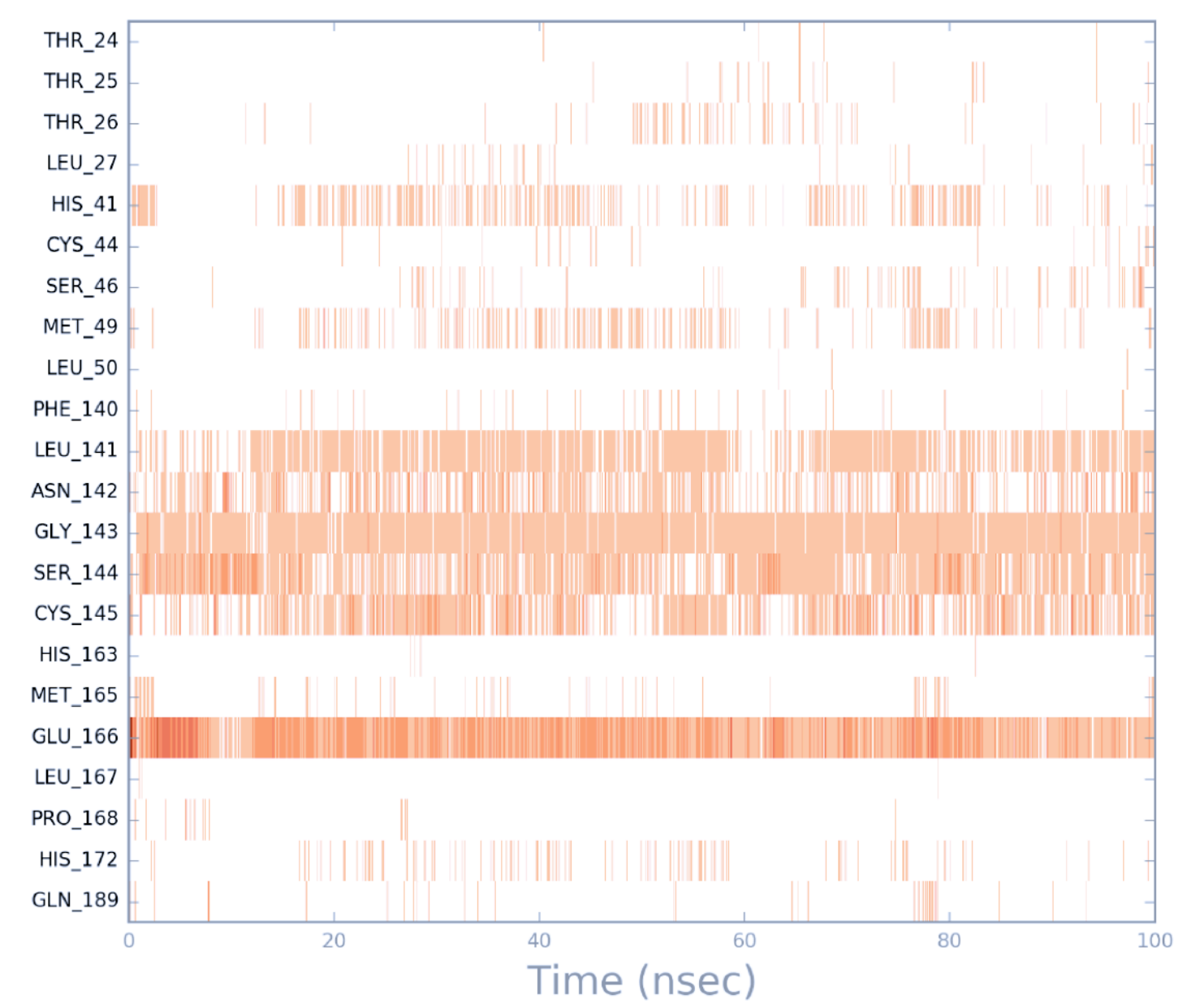

Figure S8. Ligand interactions diagram for Telinavir.
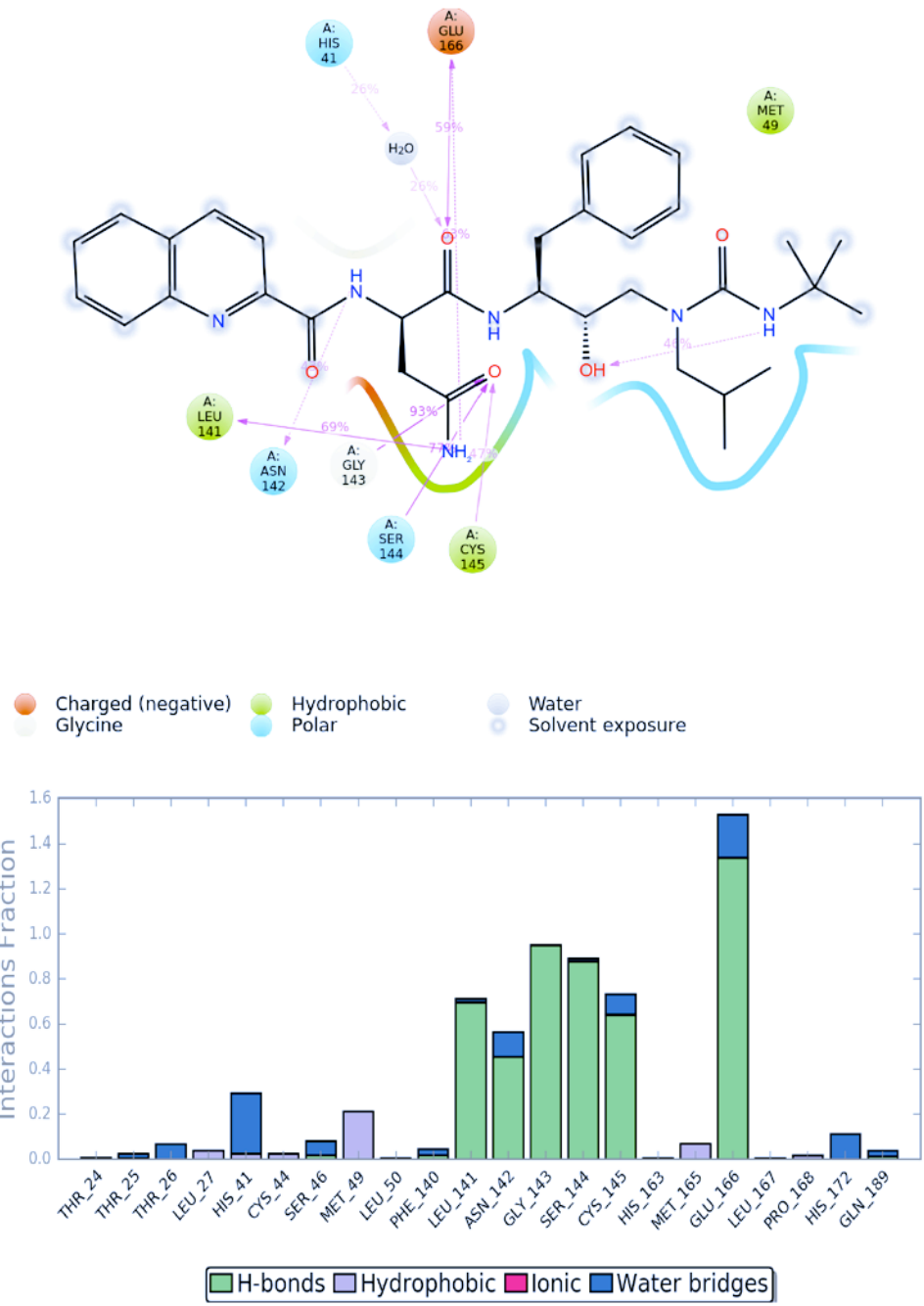

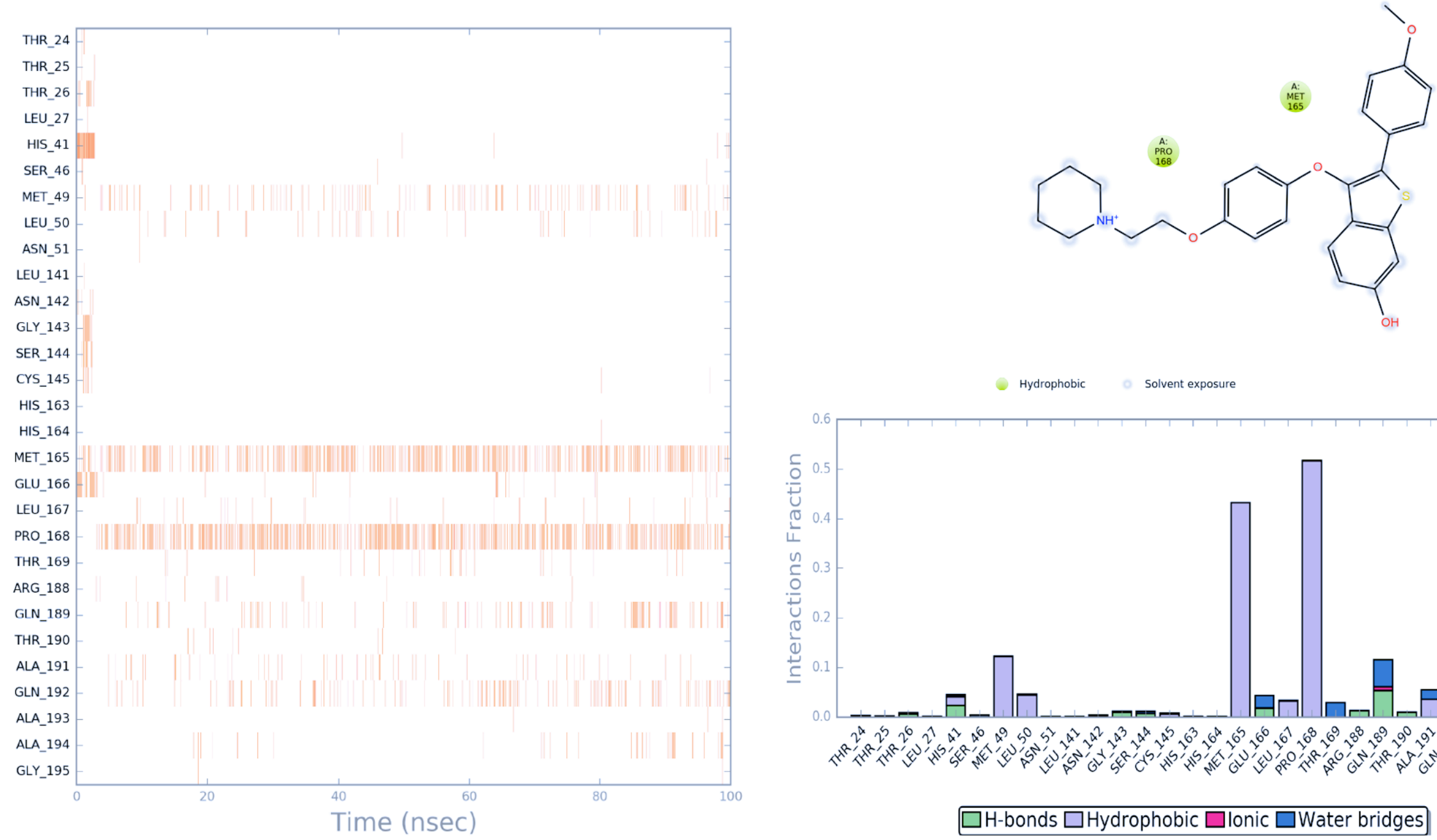

Figure S9. Ligand interactions diagram for Arzoxifen. 

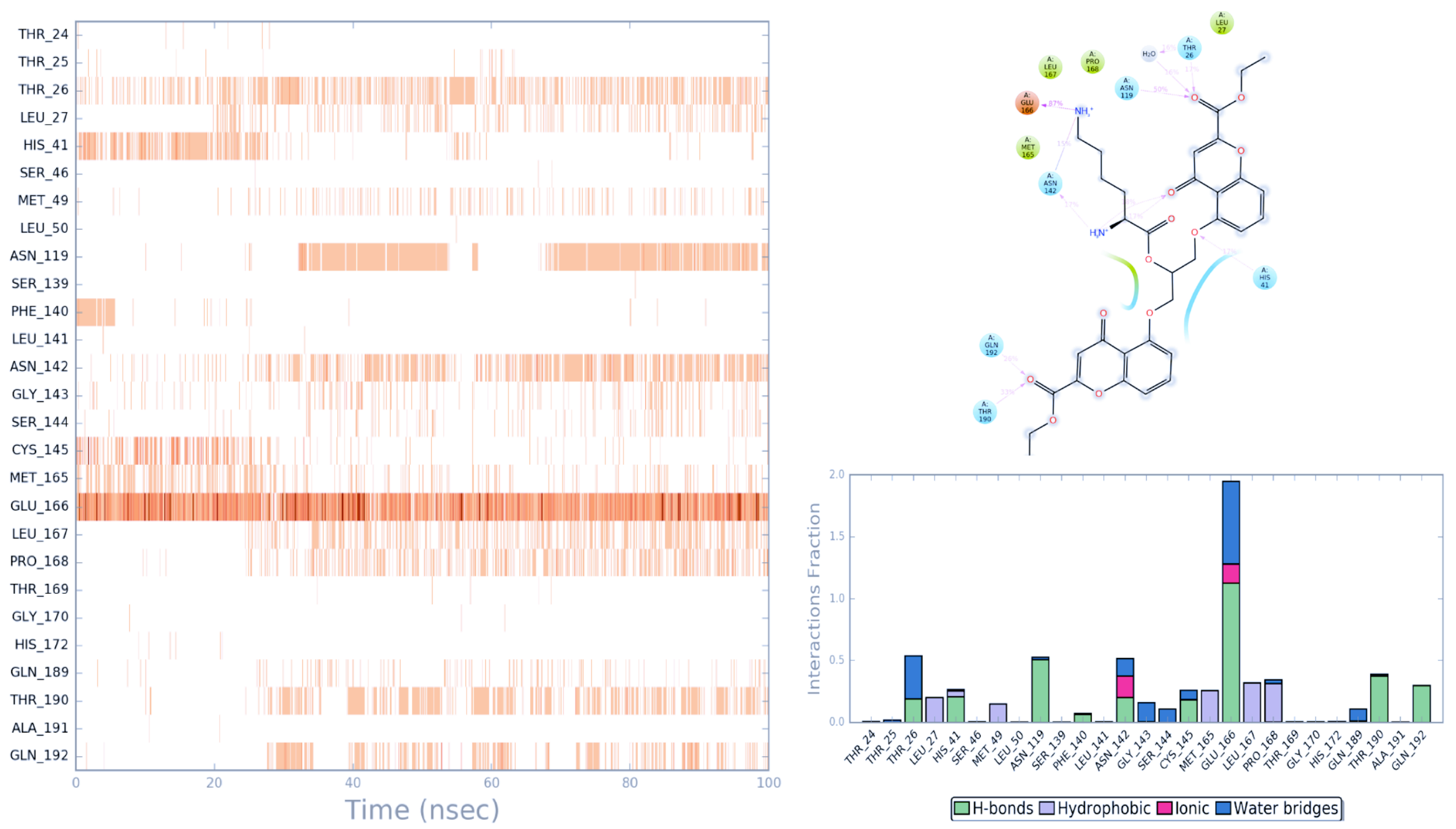

Figure S10. Ligand interactions diagram for 1,3-Bis-(2-ethoxycarbonylchromon-5-yloxy)-2-(lysyloxy)propane 

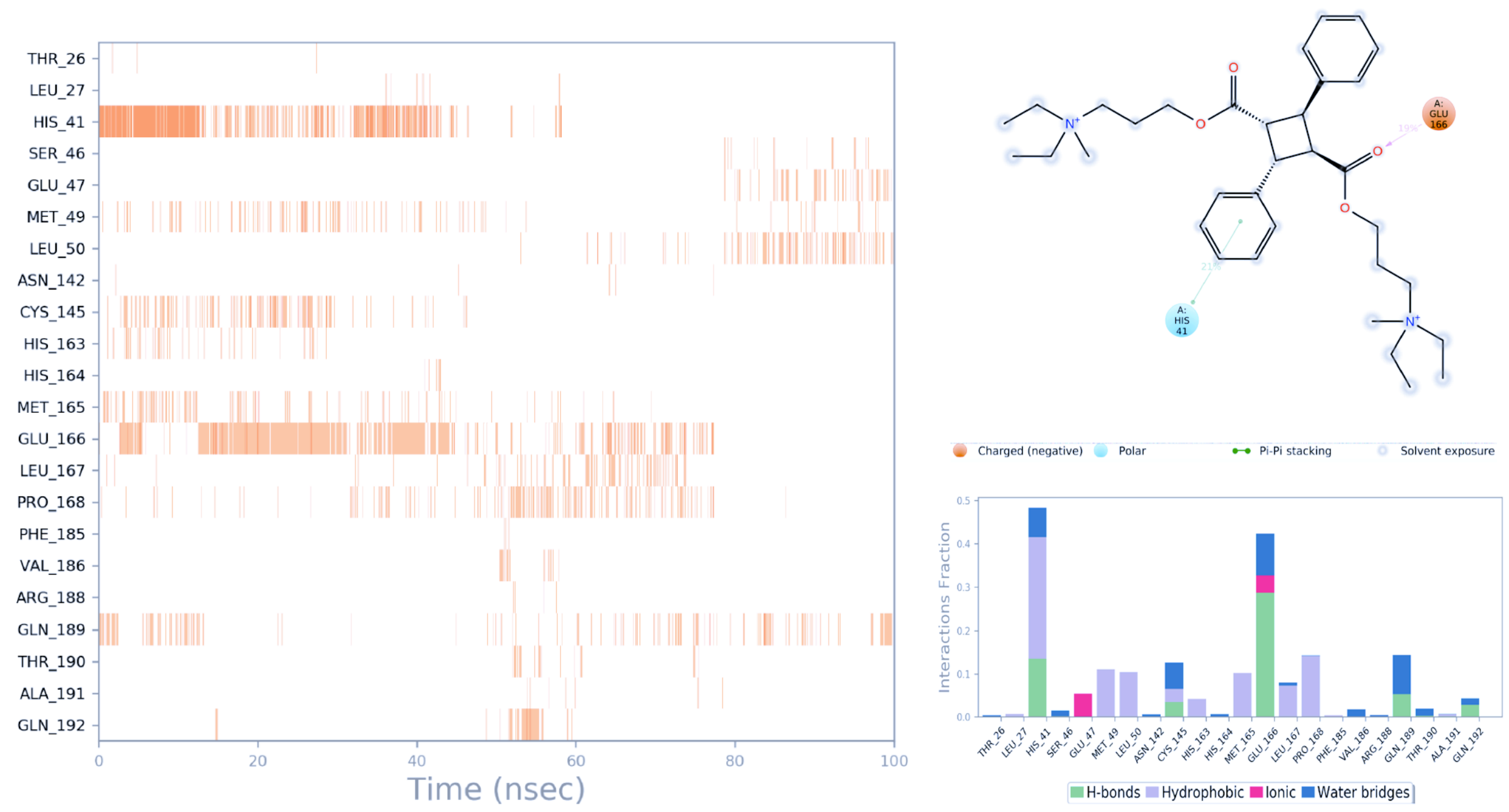

Figure S11. Ligand interactions diagram for Truxicurium. 